\title{
The Current and Potential Application of Medicinal Cannabis Products in Dentistry
}

\author{
Henry Lowe ${ }^{1,2,3,4}$, Ngeh Toyang ${ }^{2,3}$ (D) Blair Steele ${ }^{1, *}$, Joseph Bryant ${ }^{1}$, Wilfred Ngwa ${ }^{5,6}$ and Kaveh Nedamat ${ }^{7,8}$ \\ 1 Biotech R \& D Institute, University of the West Indies, Mona 99999, Jamaica; lowebiotech@gmail.com (H.L.); \\ jbryant@ihv.umaryland.edu (J.B.) \\ 2 Vilotos Pharmaceuticals Inc., Baltimore, MD 21202, USA; ngeh.toyang@flavocure.com \\ 3 Flavocure Biotech Inc., Baltimore, MD 21202, USA \\ 4 Department of Medicine, University of Maryland Medical School, Baltimore, MD 21202, USA \\ 5 Brigham and Women's Hospital, Dana-Farber Cancer Institute, Harvard Medical School, \\ Boston, MA 02215, USA; wngwa@bwh.harvard.edu \\ 6 School of Medicine, Johns Hopkins University, Baltimore, MD 21218, USA \\ 7 Sloan School of Management, Massachusetts Institute of Technology, Cambridge, MA 02142, USA; \\ nedamat@mit.edu \\ 8 Auraleaf Innovations, Toronto, ON M9B 4H6, Canada \\ * Correspondence: blairgsteele@gmail.com; Tel.: +876-926-8502
}

check for updates

Citation: Lowe, H.; Toyang, N.; Steele, B.; Bryant, J.; Ngwa, W.; Nedamat, K. The Current and Potential Application of Medicinal Cannabis Products in Dentistry. Dent. J. 2021, 9, 106. https://doi.org/ $10.3390 /$ dj9090106

Academic Editors: Claude Jaquiéry, Patrick R. Schmidlin and

Luca Testarelli

Received: 28 July 2021

Accepted: 31 August 2021

Published: 10 September 2021

Publisher's Note: MDPI stays neutral with regard to jurisdictional claims in published maps and institutional affiliations.

Copyright: (c) 2021 by the authors. Licensee MDPI, Basel, Switzerland. This article is an open access article distributed under the terms and conditions of the Creative Commons Attribution (CC BY) license (https:/ / creativecommons.org/licenses/by/ $4.0 /)$.

\begin{abstract}
Oral and dental diseases are a major global burden, the most common non-communicable diseases (NCDs), and may even affect an individual's general quality of life and health. The most prevalent dental and oral health conditions are tooth decay (otherwise referred to as dental caries/cavities), oral cancers, gingivitis, periodontitis, periodontal (gum) disease, Noma, oro-dental trauma, oral manifestations of HIV, sensitive teeth, cracked teeth, broken teeth, and congenital anomalies such as cleft lip and palate. Herbs have been utilized for hundreds of years in traditional Chinese, African and Indian medicine and even in some Western countries, for the treatment of oral and dental conditions including but not limited to dental caries, gingivitis and toothaches, dental pulpitis, halitosis (bad breath), mucositis, sore throat, oral wound infections, and periodontal abscesses. Herbs have also been used as plaque removers (chew sticks), antimicrobials, analgesics, anti-inflammatory agents, and antiseptics. Cannabis sativa L. in particular has been utilized in traditional Asian medicine for tooth-pain management, prevention of dental caries and reduction in gum inflammation. The distribution of cannabinoid (CB) receptors in the mouth suggest that the endocannabinoid system may be a target for the treatment of oral and dental diseases. Most recently, interest has been geared toward the use of Cannabidiol (CBD), one of several secondary metabolites produced by C. sativa L. CBD is a known anti-inflammatory, analgesic, anxiolytic, anti-microbial and anti-cancer agent, and as a result, may have therapeutic potential against conditions such burning mouth syndrome, dental anxiety, gingivitis, and possible oral cancer. Other major secondary metabolites of $C$. sativa L. such as terpenes and flavonoids also share anti-inflammatory, analgesic, anxiolytic and anti-microbial properties and may also have dental and oral applications. This review will investigate the potential of secondary metabolites of C. sativa L. in the treatment of dental and oral diseases.
\end{abstract}

Keywords: Cannabis sativa L.; cannabinoids; periodontitis; gingivitis; dental caries

\section{Introduction}

Oral and dental diseases contribute to a significant economic burden of productivity loss, particularly in low- and middle-income countries that lack the appropriate resources to treat such conditions. Regions such as Western Europe, Australasia, Central Europe, High-Income North America, and High-Income Asia Pacific were found to have the highest levels of per capita dental expenditures, with untreated dental caries (tooth decay) being the most prevalent health condition [1]. On the same tangent, oral cancers have a very high mortality rate in Jamaica [2]. 
In 2010, the global economic impact of dental diseases was reported to be an estimated USD 442 billion [3]. In 2015, the estimated direct and indirect costs of dental diseases totalled to USD 544.41 billion [1]. Regions with the highest levels of per capita dental expenditures included North America, Australasia, Western Europe, Asia Pacific and East Asia [1].

Additionally, in 2015, severe tooth loss was estimated to account for $67 \%$ of global productivity loss due to dental diseases [1]. Severe periodontitis (21\%) and untreated caries (12\%) followed [1]. In 2017, the global economic impact of productivity loss due to periodontitis was estimated to be EUR 44.28 B (USD 54 B) and EUR 20.50 B (USD 25 B) in direct and indirect costs, respectively [4]. In 2018, the economic impact of productivity loss due to periodontal disease in the Europe and the U.S.A. was estimated at EUR $149.52 \mathrm{~B}$ and EUR 122.65 B, respectively [5], with oral diseases affecting an estimated 3.5 billion people [6].

Table 1 is a list of the most common dental and oral diseases.

Table 1. The most common oral and dental diseases and the global prevalence of each.

\begin{tabular}{|c|c|c|c|}
\hline & Dental and Oral Diseases & Prevalence/Incidence & Reference \\
\hline \multirow[t]{3}{*}{1.} & Dental Caries/Cavities (Tooth Decay) & & \multirow[b]{3}{*}[6]{} \\
\hline & i Dental caries of permanent teeth & 2.3 billion & \\
\hline & ii Dental caries of primary teeth in children & 530 million & \\
\hline 2. & Gum (Periodontal) Disease including gingivitis & $10 \%$ of global population & [7] \\
\hline 3. & Periodontitis (severe periodontal disease) & $20-50 \%$ of global population & {$[8,9]$} \\
\hline 4. & $\begin{array}{l}\text { Oral Cancer (that is, cancers of the lip, oral } \\
\text { cavity, and oropharynx) }\end{array}$ & 657,000 new cases annually & [6] \\
\hline 5. & Oro-dental trauma & $\begin{array}{l}\text { Approximately } 1 \text { billion people } \\
\text { have had traumatic dental injuries } \\
\text { (TDIs) at some point in their lives. }\end{array}$ & [10] \\
\hline
\end{tabular}

\subsection{History of Herbal Remedies to Treat Oral and Dental Diseases}

Medicinal plants such as Acacia catechu (L.f.) Willd., Spilanthes spp., Wrightia tinctoria R.Br., Cannabis sativa L., Ophiopogonis radix, Salvia officinalis L., Syzygium aromaticum (L.) Merr. and L.M.Perry (clove), Allium sativum L. (garlic), and Datura stramonium L. have been utilized across traditional Asian, African and Indian medicine for several hundred, and possibly thousand years, to treat many ailments. These include oral and dental diseases such as oral ulcers, periodontal abscesses, oral mucositis, oral microbial infections, oral inflammatory diseases, toothache, pyorrhea, acute dental pulpitis, halitosis and sore throat [11-22]. More recently, traditional Chinese medicine (TCM) has been utilized in the treatment of oral diseases including, but not limited to oral lichen planus, recurrent aphthous stomatitis, oral leukoplakia, and Sjögren's syndrome [11].

In addition to utilization in other traditional medicinal systems, medicinal plants such as Mentha piperita L. (peppermint), Melaleuca alternifolia (Maiden and Betche) Cheel (tea tree oil), Calendula officinalis L., Aloe vera L., Citrus limon (L.) Osbeck, Camomilla matriciana, Rosmarinus officinalis L. (rosemary), Thymus vulgaris L. (thyme), and Eugenol (a compound produced by multiple medicinal plants), are also widely utilized in western complementary medicine in the treatment of oral and dental diseases [23-26].

\subsection{History of Cannabis sativa L. in the Treatment of Oral and Dental Diseases}

Cannabis sativa L. has a long history in traditional Asian, African and Indian medical systems/pharmacopoeias, for the treatment of oral and dental diseases since at least 2700BC in China $[27,28]$. As it relates to the treatment of oral and dental disease, in these traditional medical systems C. sativa L., was utilized for toothache management, though it is also likely that the plant may have also been used in the treatment and prevention of dental caries and reduction in gum inflammation [29].

C. sativa L. produces many pharmacologically active secondary metabolites including cannabinoids, terpenes and flavonoids that share anti-inflammatory, antioxidant antimicrobial, analgesic, anti-cancer, anxiolytic properties [30-39]. This, along with the finding 
that cannabinoid receptors are also distributed within the oral cavity has resulted in an increased focus toward alternative, cannabinoid-based pharmaceutical compositions for the maintenance of oral health and in the treatment of oral diseases.

There is also an increasing shift toward alternative natural oral hygiene products. One major reason is the increasing resistance to synthetical antimicrobials and the possible adverse effects of chemical agents [40]. To date, cannabinoid-based pharmaceutical compositions have been patented for the maintenance of general oral hygiene and for specific oral and dental diseases. Table 2 below lists examples of such patents.

This review will attempt to make an argument for the therapeutic potential of secondary metabolites of $C$. sativa $\mathrm{L}$. against oral and dental diseases, based on the aforementioned therapeutic properties of metabolites and the implication of the ECS in oral and dental diseases. However, further studies will be required to elucidate mechanisms of action, efficacies, safeties and toxicities of these secondary metabolites.

\section{Current Uses of Cannabinoids in Modern Dentistry}

There is currently a wide range of cannabinoid-based oral products currently on the market, and studies being conducted on cannabinoid-based pharmaceuticals in general, are increasingly positive and evidence-based. These products include cannabidiol (CBD) capsules, CBD pills, CBD Hemp Oil Tinctures, CBD Oil, CBD-infused toothpastes, CBD Oral Sprays, CBD-infused mouthwashes, CBD chewing gum and even CBD-infused dental fillings [40-43]. The aforementioned products are primarily used as analgesics to provide relief from tooth pain and gum soreness, and as anti-microbials and anti-septic agents to maintain oral hygiene, and anti-inflammatory agents to control inflammation of the gums $[44,45]$. Despite the myriad of existing cannabinoid-based oral products, the scientific literature on the safety, efficacy, toxicity and quality of these pharmaceuticals, is limited. Ultimately, the regulatory framework governing these compounds and their use thereof, as defined by the U.S. Food and Drug Administration, is also in its nascent stage of development. On this tangent, it is suggested that patients seek professional medical advice before using cannabinoid-based oral products. These regulatory frameworks are built on rigorous, scientific- and evidence-based data, which are currently lacking.

In one preliminary observation, scientists found that cannabinoids were more effective in reducing bacterial colony count in dental plaques when compared to Colgate and Oral B, industry-standard, synthetic oral hygiene products [46]. Due to antimicrobial resistance, it was then concluded that these cannabinoids may be a safer alternative to traditional synthetic oral hygiene products [46]. In another study, the efficacy of two mouthwash products, one containing a $<1 \%$ cannabidiol (CBD) per weight and another containing $<1 \%$ cannabigerol (CBG) per weight, respectively, were investigated against total-culturable bacteria from dental plaque samples [47]. In comparison to chlorhexidine $0.2 \%$, frequently used in traditional synthetic mouthwash, both cannabinoid-infused mouthwash products demonstrated very similar bactericidal efficacy [47].

Table 2. Examples of cannabinoid-based pharmaceutical compositions have been patented for the maintenance of general oral hygiene and for specific oral and dental diseases.

\section{Utility}

Reference

(Patent Number)

Cannabis-based composition comprising cannabis-extract, derivatives, and/or at least one

1. synthetic cannabinoid intended for the treatment of dental pulp infection, pulp inflammation, dental (jaw) bone defects

Cannabinoid-based oral care composition (tooth paste, a tooth powder, or a mouthwash solution)

2. for the treatment of oral infectious disease, including periimplantitis, periodontitis, oral mucositis, and dental pain. Cannabinoid may be cannabidiol and/or cannabigerol.

3. Extract of C. sativa L. (toothpaste, oral cleanser, or oral spray) for the treatment of dental caries.

4. Cannabinoid-based chewing gum compositions intended for the alleviation of pain. 


\subsection{Targeting the Endocannabinoid System (ECS)}

The Endocannabinoid System (ECS) is a network of proteins (receptors, their ligands and biosynthesis and degradative enzymes) widely distributed throughout mammalian tissues and cells in virtually animal species [52,53]. The ECS is primarily responsible for maintaining internal homeostasis and directly influences physiological process regulating anxiety, feeding behavior/appetite emotional behavior, depression, nervous functions, endocrine regulation, energy balance, neurogenesis, neuroprotection, reward, cognition, learning, memory, pain, sensation, fertility, pregnancy, and pre-and post-natal development [54-62]. The ECS plays a role in multiple physiological and pathophysiological processes, making it a valuable target for the treatment of many diseases and disorders such as multiple types of cancers, cardiovascular diseases, neurodegenerative diseases, psychiatric disorders, mood and anxiety disorders, obesity, and substance-abuse disorders [63-75]. On the same tangent, it is also suggested that Squamous Cell Carcinoma of the Oral Tongue (SCCOT) may be the result of a dysregulation of endocannabinoid system signaling [76].

Phytocannabinoids, referred to as classical cannabinoids, are a class of terpenophenolic compounds that are naturally produced by C. sativa L. plant $[77,78]$. Over 100 cannabinoids have been isolated from C. sativa L. to date [79]. The two major, most studied and most abundantly produced phytocannabinoids are $\Delta^{9}$-THC ( $\Delta^{9}$-Tetrahydrocannabinol) and Cannabidiol (CBD). Others include Tetrahydrocannabivarin (THCV), Cannabigerovarin (CBGV), Cannabichromene (CBC), Cannabichromevarin (CBCV), Cannabigerol (CBG), Cannabivarin (CBDV), Cannabivarin (CBV), and Cannabicyclol (CBL). The chemical structures of major secondary metabolites produced by C. sativa L. are shown in Table 3 below.

Due to the potent properties of the major cannabinoids, they may have therapeutic potential against oral and dental diseases. Other major secondary metabolites produced by C. sativa L. that have a wide range of significant of therapeutic benefits are flavonoids and terpenes. Secondary metabolites are organic compounds produced by microorganisms and plants that play roles in a number of processes that give the plant or microorganism comparative advantage, may play a role in survival of the microorganism or plant, play a role in the aroma (terpenes), pigmentation and flavour of the plant (flavonoids), and that may have pharmacological/health benefits [80-83]. In addition to these roles, many cannabinoid- and non-cannabinoid secondary metabolites produced by C. sativa L., are analgesic, antimicrobial, anti-cancer, anti-inflammatory, anxiolytic, anti-depressant, relaxant, and antioxidant [35,39,84-94].

Together these cannabinoids and non-cannabinoid molecules work synergistically to enhance the biological effect of C. sativa L. This is known as the "Entourage Effect" [95-97]. As such, pharmaceuticals made of these secondary metabolites may have a role in the treatment of oral and dental diseases. Table 3 lists major secondary metabolites of $C$. sativa $\mathrm{L}$. and their properties that could make them useful in dentistry.

Table 3. Chemical structures of the major secondary metabolites (cannabinoids, terpenes and flavonoids) of Cannabis sativa L. with potent properties that may make them useful in the treatment of oral and dental diseases.

\begin{tabular}{lll}
\hline Chemical Structures of Major Secondary Metabolites of Cannabis sativa L. & Significant Properties & References \\
\hline Major cannabinoids & $\begin{array}{l}\text { Anti-microbial } \\
\text { Anti-inflammatory } \\
\text { Analgesic } \\
\text { Antioxidant } \\
\text { Anti-cancer } \\
\text { Anti-tumor }\end{array}$ & [84,98-105] \\
\hline
\end{tabular}


Table 3. Cont.

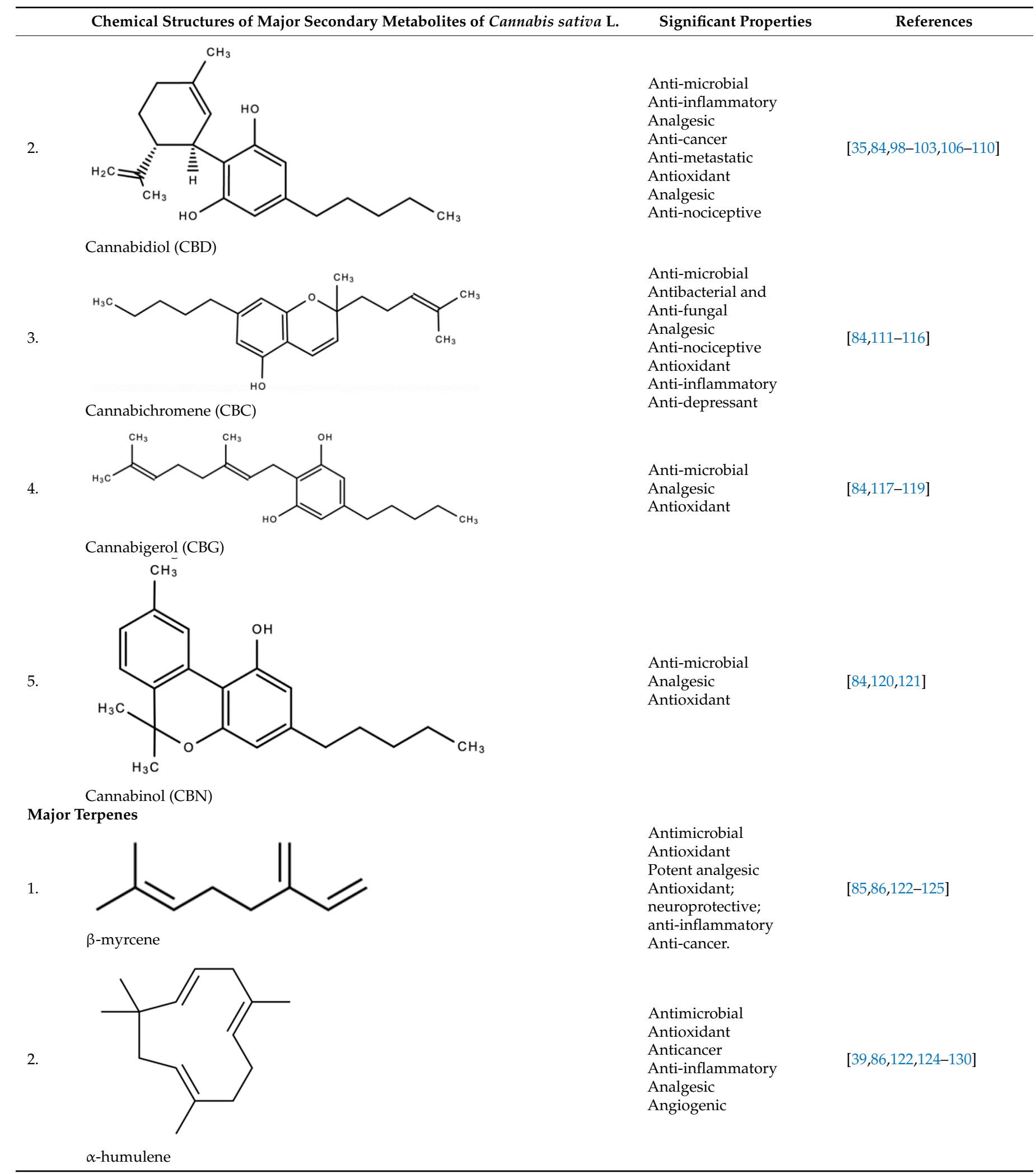


Table 3. Cont.

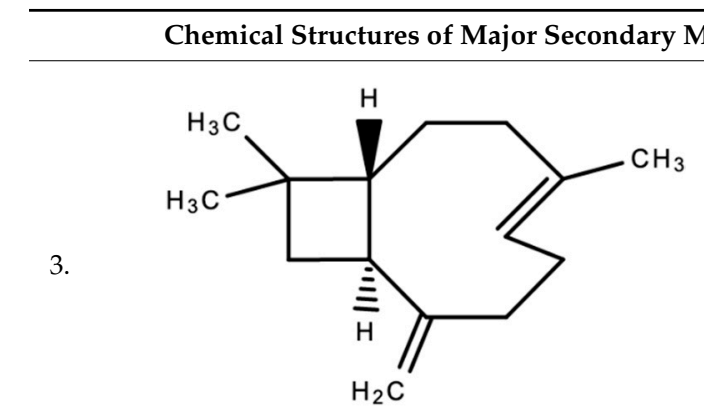

Antimicrobial

Antioxidant

Anti-Cancer

Anti-inflammatory

Analgesic

Anxiolytic

Antimicrobial

Anti-inflammatory

Antioxidant

$[92,122,123,125]$

Analgesic

Antifungal; antibacterial antioxidant; antiviral; anti-inflammatory

Antimicrobial

Antioxidant

Analgesic

Anti-inflammatory;

antioxidant; antiviral;

antidiabetic; anticancer

Antidepressant;

Anticonvulsant

Anti-cancer

Anxiolytic

(-)-limonene

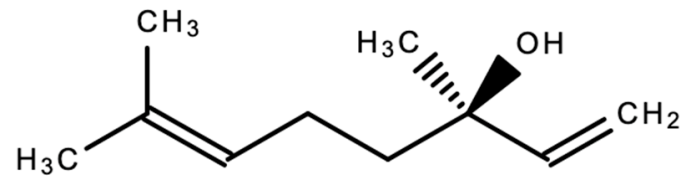

Linalool (Lavender scent)

8.<smiles>CC1=CCC(C(C)(C)O)CC1</smiles>

Antimicrobial;

Anti-inflammatory;

Analgesic; Nociception

$[35,92,122,125,141,142]$

Anxiolytic

anti-inflammatory;

antimicrobial; anticancer; $\quad[39,85,122,125]$

antidepressant

Antioxidant
$[35,86,122,125,135-140]$
$[86,122,125,130-134]$ inhibition; Antimicrobial 
Table 3. Cont.

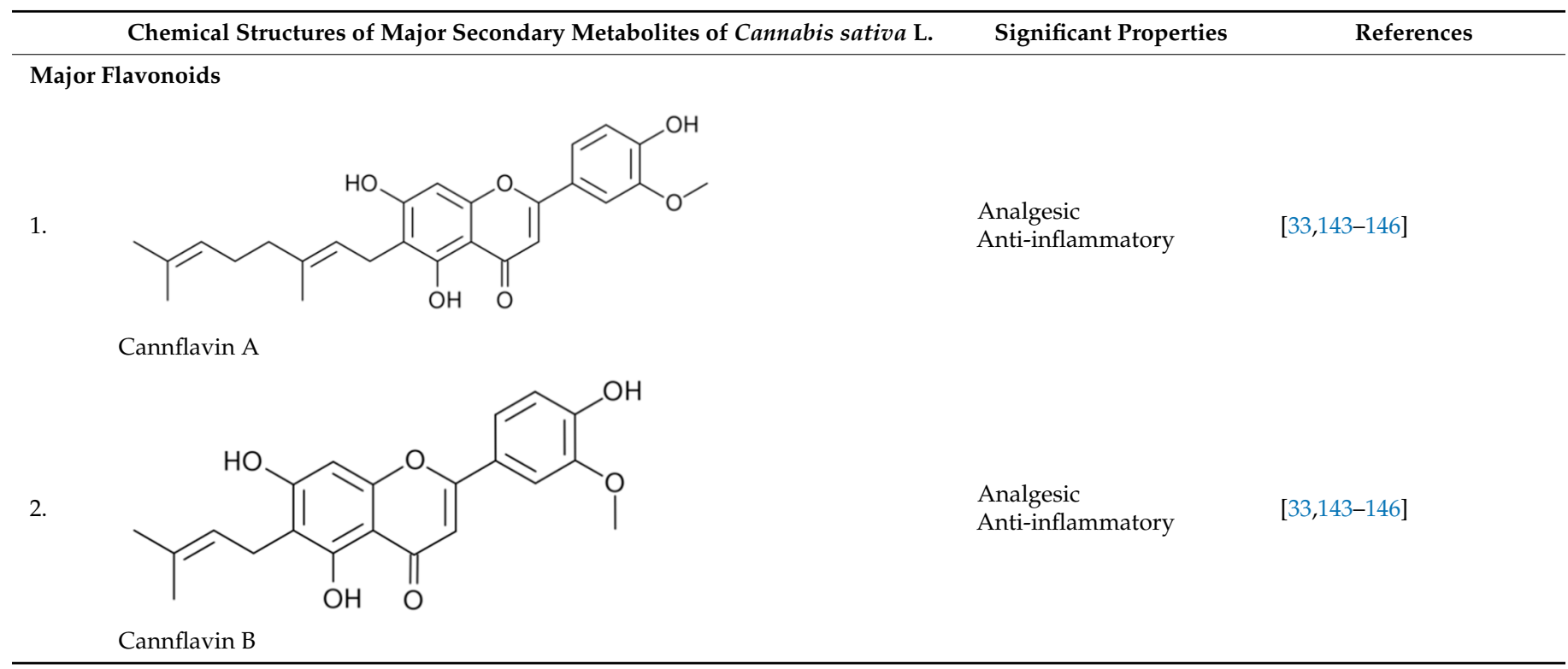

Endogenous cannabinoids such as Anandamide (AEA/N-arachidonoylethanolamine) and Palmitylethanolamide (PEA) have also demonstrated analgesic effects [147]. Synthetic cannabinoids such as HU-120, HU-308, HU-320, WIN-55,212-2, JWH-133, JWH-015, nabilone, also demonstrate analgesic, anti-microbial, anti-inflammatory, anti-cancer, antiangiogenic, anti-metastatic properties and may also be useful in the treatment of oral and dental diseases [148-155].

\subsection{Implications of Cannabinoid Receptors in the Mouth}

Cannabinoid receptors such as the transient receptor potential vanilloid channel type $1\left(\mathrm{TRPV}_{1}\right)$, cannabinoid receptors type $1\left(\mathrm{CB}_{1}\right)$ and cannabinoid receptors type 2 $\left(\mathrm{CB}_{2}\right)$ in addition to other cannabinoid receptors located in the salivary glands may be novel therapeutic targets in the treatment of certain oral diseases [156-158]. Cannabinoid receptors located in salivary glands (particularly submandibular acinar cells) have also been implicated in the regulation of salivation and saliva content and thus may even be useful in the treatment of Xerostomia ("dry-mouth") [158,159]. On this same tangent, AM251 and AM630, CB1 and CB2 antagonists, respectively, were shown to block the inhibitory effects of anandamide (AEA) on saliva secretion, and in doing so, increased saliva secretion [158].

\subsection{Potential Applications of CBD and Other Secondary Metabolites in Modern Dentistry} 2.3.1. Emerging Trends and Potential Value of Medical Cannabis in Dentistry

Now than ever before, there is an increasing acceptance of the use of medical cannabis in Dentistry. Dentists are increasingly exploring and inventing more innovative, natural, safer, and more efficient, but less expensive alternatives to traditional synthetic oral medications. Despite this increasing interest, more rigorous scientific studies are required on cannabinoid-based oral products. The financial potential for cannabis-based oral hygiene products is also very promising, especially with the growth in demand and innovation in the field.

\subsubsection{Toothache}

Toothaches are a global, public health crisis and are one of the most common, if not the most common dental disease and the most common cause of oral pain $[160,161]$. Toothaches may typically be caused by an irritation, infection, or injury to the tooth, hypersensitivity of the nerves, damage to surrounding structures of the tooth, or decay of the tooth. 
Although studies are limited and mechanisms of action not yet elucidated, the analgesic properties of cannabinoids such as Delta 9-tetrahydrocannabinol ( $\Delta^{9}$-THC), Cannabidiol (CBD) and Cannabigerol (CBG) have implicated them in the treatment of toothaches $[41,162,163]$. The analgesic properties of the cannabinoids may also make them useful in pain-management for tooth extractions and post-operative pain management.

\subsubsection{Burning Mouth Syndrome}

Burning Mouth Syndrome is a neuropathic pain condition of the tongue, lips, gum, palate and/or other areas of the oral cavity, which is characterized by chronic or recurrent burning sensation $[164,165]$. Although the causes have not been fully elucidated, studies suggest that the condition may be due to dysregulation of the taste and sensory nerves of the peripheral or central nervous system [166-168]. Multiple studies have investigated and confirmed the safety and efficacy of cannabinoids, in some form or another, against the symptoms of Burning Mouth Syndrome [169].

Components of the ECS have been implicated in the pathogenesis of Burning Mouth Syndrome [156,170]. A 2014 study by Borsani and colleagues identified an increase in the expression of transient receptor potential vanilloid channel type $1\left(\mathrm{TRPV}_{1}\right)$ and cannabinoid receptors type $2\left(\mathrm{CB}_{2}\right)$, but a decrease in expression of cannabinoid receptors type $1\left(\mathrm{CB}_{1}\right)$ in epithelial cells of the tongue $[156,170]$. These studies suggest that the endocannabinoid system may be a potential target for the treatment of Burning Mouth Syndrome.

\subsubsection{Dental Caries}

Dental caries, more simply referred to as "cavities" or "tooth decay", is a very common condition that affects approximately 2.3 billion people worldwide, including 530 million children [6]. Dental caries is the result of several factors including plaque- and biofilmforming bacteria such as Streptococcus mutans or Lactobacillus spp., frequent intake of sugary foods that cause acid build-up, lack of adequate teeth cleaning and subsequent demineralization/erosion of the enamel.

Due to antibacterial properties, cannabidiol may have therapeutic applicability in the treatment of dental caries [47]. Other major cannabinoids such as cannabichromene, cannabigerol, Delta (9)-tetrahydrocannabinol, and cannabinol also demonstrated potent antibacterial activity against a variety of clinically relevant methicillin-resistant Staphylococcus aureus (MRSA) strains and so, may also have anti-bacterial activity against bacteria implicated in oral and dental diseases $[84,94,117,118]$. Cannabinoid-infused mouthwashes have also demonstrated inhibition of bacterial activity in dental plaque samples with the same efficacy as chlorhexidine a common disinfectant and antiseptic agent [47]. Cannabidiol-supplemented tooth polishing powder has also been reported to inhibit dental plaque bacteria [47]. Numerous sources of anecdotal evidence strongly supports the use of a few drops of CBD oil per day for its antibacterial potential against said bacteria.

\subsubsection{Dental Anxiety}

Dental anxiety is a legitimate fear of anticipated pain and subsequent avoidance of professional dental care [171]. It is a phenomenon that generally begins in childhood due to conditioning from fearful parents [172,173], and is prevalent globally. Culture and norms also influence an individual's conditioning [174]. As a result, an individual's oral health will deteriorate to a point where even their general health, sleep pattern, overall quality of life, self-esteem, social interactions with others, and professional and personal relationships may be significantly affected $[174,175]$. Multiple studies even show a positive correlation between dental anxiety and the development of dental diseases [172,176-178]. Dental anxiety is a frequent and significant issue for dentists globally and has even been shown to be a contributing factor to their own stress levels $[171,179]$.

Strategies that have been developed to combat/manage dental anxiety include nonpharmacological approaches such as (1) establishment of good communication and rapport between dentist and patient, (2) systemic desensitization (3) hypnosis (4) cognitive be- 
haviour therapy, a type of psychological therapy aimed at removing the negative thoughts associated with dental anxiety and phobia, and (5) pharmacological interventions such as intravenous sedation, inhalation sedation, local and general anaesthesia [179-185].

Most recently, the therapeutic potential of cannabidiol for the treatment of dental anxiety has also been investigated due to its anxiolytic, panicolytic and anti-compulsive properties. One report suggests that 15-30 milligrams of CBD applied sublingually before a dental appointment may be efficacious against dental anxiety and dental pain [186,187].

\subsubsection{Periodontal Disease}

Periodontal disease is an inflammatory gum disease caused by bacterial plaque buildup, and characterized by inflammation and even bleeding of the gum. It may be considered the intermediate stage in the general progression of gum disease. Periodontal diseases include gingivitis (early-stage gum disease) and periodontitis (severe, advanced-stage gum disease), both of which are characterized by irritation and inflammation of the gum. If left untreated, the disease leads to progressive alveolar bone loss and eventually, tooth loss. Furthermore, these effects are not solely localized, but manifest systemically.

The endocannabinoid system may be a promising target in the treatment of periodontal disease as it has been shown to play a role in the modulation/suppression of inflammatory responses by periodontal ligament (PDL) cells $[188,189]$. The endocannabinoid anandamide (AEA) appears to play a modulatory role in periodontal inflammation and a role in the immunosuppression of human periodontal ligament cells' (hPdLCs') host response to Porphyromonas gingivalis lipopolysaccharide (P. gingivalis LPS) $[188,189]$. On the same tangent, in human patients with periodontitis, AEA expression is upregulated in gingival crevicular fluid after periodontal surgery [190]. AEA has also been shown to preservice the cellular integrity of hPdLCs [189]. Palmitoylethanolamide (PEA) also exacerbated the proinflammatory effects of AEA [189]. Cannabinoids such as THC and CBD, CBC, and CBG, demonstrate potent anti-inflammatory and analgesic effects that may make them very useful in the treatment of inflammation-based gum diseases [84,105,110,111,113,115,188-192].

Associated co-morbidities on the basis of epidemiological, clinical intervention and animal model-based studies include but are not limited to cardiovascular disease, diabetes, Alzheimer's disease, rheumatoid arthritis, cancer, adverse pregnancy outcomes, inflammatory bowel disease and respiratory disease [193].

Traditionally, much of the focus of the treatment of periodontal disease has been on reducing the bacterial load. However, an opportunity exists to modulate the host inflammatory response as well, making use of the anti-inflammatory properties of cannabinoids. Those suffering from severe periodontitis exhibit elevated levels of pro-inflammatory mediators and neutrophils in their blood and local periodontal treatment reduces these inflammatory markers systemically [194]. Of particular interest is the potential for the existence of synergistic ratios between cannabinoids which when combined, can produce optimal anti-bacterial, anti-inflammatory, antioxidant and analgesic effects. One example is between CBD and CBG where studies on neuroinflammation, a key factor in amyotrophic lateral sclerosis (ALS) show that, when combined, their benefits are enhanced [194]. More research needs to be conducted in the field of oral health to see if synergies exist for this application.

With the recent COVID-19 pandemic, researchers have been exploring the role that cytokine storms play in the viral infection and in particular, the role of interleukin-6 (IL6) [195]. Studies suggest that a predictor of COVID-19 pulmonary complications is elevated levels of IL-6. Periodontitis increase levels of IL-6 both locally and systemically meaning treatment and prevention of periodontal disease can lower levels of IL-6 and, therefore, improve respiratory outcomes of COVID-19 infection, reducing mortality [195]. In a casecontrol study, periodontitis was found to be associated with COVID-19 complications including death, ICU admission, and need for assisted ventilation [196]. Systemically, those COVID-19 patients with periodontitis showed significantly higher blood levels of white 
blood cells, D-dimer and C Reactive Protein [196]. These biomarkers are linked to worse disease outcomes.

\subsubsection{Oral Mucositis and Other Forms of Oral Cancers}

Oral mucositis is a disease characterized by inflammation and ulceration of the mucous membranes lining the gastrointestinal tract. Oral mucositis is regarded as the most common debilitating complication of cancer-related chemotherapy and radiation that kills both malignant and healthy tissues [197]. Though evidence is limited, the antioxidant properties of cannabidiol suggest that it may be used to control the oxidative stress associated with oral mucositis [198].

Cannabinoid $\mathrm{CB}_{1}$ and $\mathrm{CB}_{2}$ receptor are up-regulated in certain cancer types and thus, may be potential targets to exploit in the treatment of cancer and other diseases [199]. Multiple cannabinoids have demonstrated antioxidant, anti-metastatic, anti-tumorigenic, apoptotic and anti-angiogenic properties in various cancer cell lines and thus may have therapeutic benefits in treating oral cancers [104,157,200-209]. Table 4 lists particular potential applications of secondary metabolites against oral and dental diseases.

Table 4. Potential Applications of secondary metabolites of C. sativa L. in dentistry.

\begin{tabular}{|c|c|c|c|}
\hline & $\begin{array}{l}\text { Potential Applications of Secondary Metabolites of } \\
\text { C. sativa L. in Dentistry }\end{array}$ & $\begin{array}{l}\text { Appropriate Property of } \\
\text { Secondary Metabolite }\end{array}$ & Reference \\
\hline & Cannabinoids & & \\
\hline 1. & $\begin{array}{l}\text { General oral hygiene (Cannabidiol, delta9-tetrahydrocannabinol } \\
\text { ajulemic acid, Cannabigerol) }\end{array}$ & $\begin{array}{l}\text { Antifungal } \\
\text { Antibacterial }\end{array}$ & {$[41,84,93,105,117,118,210]$} \\
\hline 2. & $\begin{array}{l}\text { Toothache } \\
\text { (Cannabidiol, HU-320) }\end{array}$ & Analgesic & {$[41,151,163]$} \\
\hline 3. & $\begin{array}{l}\text { Dental caries/cavities (Cannabidiol, Cannabigerol and } \\
\text { Delta9-tetrahydrocannabinol) }\end{array}$ & \multirow{2}{*}{$\begin{array}{l}\text { Anti-bacterial } \\
\text { Analgesic } \\
\text { Anti-bacterial } \\
\text { Anti-pruritic }\end{array}$} & $\begin{array}{l}{[41,47,48,84,93,117,118} \\
191,211]\end{array}$ \\
\hline 4. & Abscesses (Cannabidiol and delta9-tetrahydrocannabinol) & & {$[191]$} \\
\hline 5. & $\begin{array}{l}\text { Prevention of biofilm attachment on teeth (Cannabidiol and } \\
\text { delta9-tetrahydrocannabinol) }\end{array}$ & Anti-bacterial & {$[84,191]$} \\
\hline 6. & Burning Mouth Syndrome (Cannabidiol) & \multirow{2}{*}{$\begin{array}{l}\text { Analgesic } \\
\text { Anti-cancer } \\
\text { Anti-metastatic }\end{array}$} & [191] \\
\hline 7. & Oral and Salivary Gland Cancers (Cannabidiol) & & [191] \\
\hline 8. & $\begin{array}{l}\text { Periodontitis (most severe form of gum disease) (Cannabidiol, } \\
\text { HU-320, delta9-tetrahydrocannabinol, AEA) }\end{array}$ & $\begin{array}{l}\text { Anti-bacterial } \\
\text { Anti-inflammatory } \\
\text { Analgesic }\end{array}$ & {$[84,151,188,191,212,213]$} \\
\hline 9. & $\begin{array}{l}\text { Periodontal (Gum) disease (Cannabidiol, } \\
\text { delta9-tetrahydrocannabinol, Cannabigerol and HU-320) }\end{array}$ & $\begin{array}{l}\text { Anti-bacterial } \\
\text { Anti-inflammatory } \\
\text { Analgesic }\end{array}$ & {$[84,93,117,118,151,211]$} \\
\hline 10. & $\begin{array}{l}\text { Gingivitis (Cannabidiol, delta9-tetrahydrocannabinol, } \\
\text { Cannabigerol, and HU-320) }\end{array}$ & $\begin{array}{l}\text { Anti-bacterial } \\
\text { Anti-inflammatory } \\
\text { Analgesic } \\
\text { Anti-bacterial }\end{array}$ & {$[84,93,117,118,151,211]$} \\
\hline 11. & $\begin{array}{l}\text { Oral Mucositis and other forms of oral cancer (Cannabidiol, } \\
\text { delta9-tetrahydrocannabinol, JWH-133m, WIN-55,212-2, } \\
\text { Cannabinol, Cannabicyclol) }\end{array}$ & $\begin{array}{l}\text { Anti-cancer } \\
\text { Anti-metastatic } \\
\text { Anti-inflammatory } \\
\text { Analgesic } \\
\text { Antioxidant }\end{array}$ & {$[84,154,191,192,198,214]$} \\
\hline 12. & Dental Anxiety (Cannabidiol) & Anxiolytic & {$[191,215]$} \\
\hline 13. & $\begin{array}{l}\text { Sleep issues resulting from dental anxiety } \\
\text { (Cannabidiol and delta-9-tetrahydrocannabinol (THC)) }\end{array}$ & Relaxant & {$[216]$} \\
\hline 14. & $\begin{array}{l}\text { Indirect enamel protectant } \\
\text { (Cannabidiol and delta-9-tetrahydrocannabinol (THC)) }\end{array}$ & $\begin{array}{l}\text { The anti-bacterial properties of } \\
\text { CBD and THC could indirectly } \\
\text { protect the enamel by prevent } \\
\text { plaque build-up that could } \\
\text { ultimately lead to erosion of the } \\
\text { enamel. }\end{array}$ & {$[84,191]$} \\
\hline 15. & Remineralization of enamel (Hemp oil) & & [211] \\
\hline 16. & $\begin{array}{l}\text { Improvement of tooth sensitivity (Hemp seed oil, Cannabigerol, } \\
\text { and CBD oil) }\end{array}$ & & {$[211,216-218]$} \\
\hline 17. & $\begin{array}{l}\text { Stimulation of jaw bone osteogenesis/regeneration (Cannabidiol } \\
\text { and delta-9-tetrahydrocannabinol (THC)) }\end{array}$ & $\begin{array}{l}\text { Stimulates osteogenesis in bone } \\
\text { fracture healing }\end{array}$ & [219-222] \\
\hline
\end{tabular}


Table 4. Cont.

\begin{tabular}{|c|c|c|c|}
\hline & $\begin{array}{l}\text { Potential Applications of Secondary Metabolites of } \\
\text { C. sativa L. in Dentistry }\end{array}$ & $\begin{array}{l}\text { Appropriate Property of } \\
\text { Secondary Metabolite }\end{array}$ & Reference \\
\hline 18. & $\begin{array}{l}\text { Decrease in bone resorption in experimental periodontitis in rats } \\
\text { (Cannabidiol) }\end{array}$ & $\begin{array}{l}\text { Anti-inflammatory } \\
\text { Decreases alveolar bone loss (in } \\
\text { rat model) }\end{array}$ & [223] \\
\hline 19. & $\begin{array}{l}\text { Salivary gland bacterial infection (Cannabidiol and } \\
\text { delta9-tetrahydrocannabinol, cannabigerol) }\end{array}$ & $\begin{array}{l}\text { Anti-bacterial } \\
\text { Anti-inflammatory } \\
\text { Analgesic }\end{array}$ & {$[93,117,118,191,224,225]$} \\
\hline 20. & $\begin{array}{l}\text { Digestive issues associated with anesthesia and numbing agents } \\
\text { (Cannabidiol) }\end{array}$ & $\begin{array}{l}\text { Anti-emetic } \\
\text { Anti-nauseant }\end{array}$ & [216] \\
\hline 21. & Temporomandibular Joint (TMJ) Disorder (Cannabidiol) & Analgesic & {$[226]$} \\
\hline \multirow[t]{2}{*}{22.} & $\begin{array}{l}\text { Osseointegration of dental implants (HU-308-a CB2-specific } \\
\text { agonist) }\end{array}$ & $\begin{array}{l}\text { Stimulation of osteoblastic bone } \\
\text { formation and inhibition of } \\
\text { osteoclastic bone resorption via } \\
\text { activation of CB2 receptors in } \\
\text { osteoblasts and osteoclast, and } \\
\text { subsequent maintenance of bone } \\
\text { mass. }\end{array}$ & [227] \\
\hline & Flavonoids & & \\
\hline 1. & $\begin{array}{l}\text { Toothaches, } \\
\text { (Cannflavins A and B) }\end{array}$ & $\begin{array}{l}30 \times \text { more analgesic than aspirin } \\
\text { Anti-inflammatory }\end{array}$ & {$[33,143,144,228]$} \\
\hline 2. & $\begin{array}{l}\text { Oral cancers that are characterized by increased production of } \\
\text { reactive oxygen species. } \\
\text { (Flavonols (e.g., quercetin and kaempferol)) }\end{array}$ & Antioxidant; & [229] \\
\hline 3. & $\begin{array}{l}\text { Inflammation-based oral diseases such. Oral cancers that are } \\
\text { characterized by increased production of reactive oxygen species. } \\
\text { (Flavanones) }\end{array}$ & $\begin{array}{l}\text { Antioxidant; anticancer; } \\
\text { anti-inflammatory }\end{array}$ & [229] \\
\hline 4. & $\begin{array}{l}\text { Inflammation-based oral diseases. Oral cancers that are } \\
\text { characterized by increased production of reactive oxygen species. } \\
\text { (Anthocyanins) }\end{array}$ & $\begin{array}{l}\text { Antioxidant and } \\
\text { anti-inflammatory }\end{array}$ & [229] \\
\hline & Terpenes & & \\
\hline 1. & $\begin{array}{l}\text { Toothache and other oral disorders that cause pain } \\
\text { ( } \beta \text { - caryophyllene, } \alpha \text {-terpineol, Myrcene) }\end{array}$ & Analgesic & {$[35,85,86,92,141,142]$} \\
\hline 2. & $\begin{array}{l}\text { Dental Anxiety } \\
\text { (E.g. Linalool) }\end{array}$ & Anxiolytic & [86] \\
\hline 3. & $\begin{array}{l}\text { Inflammation-based oral diseases such as gingivitis, periodontal } \\
\text { disease and periodontitis. } \alpha \text {-terpineol(Linalool, Myrcene, } \alpha \text {-Pinene, } \\
\text { Ocimene, } \beta \text {-caryophyllene, Limonene) }\end{array}$ & Anti-inflammatory & {$[85,92]$} \\
\hline 4. & $\begin{array}{l}\text { Oral cancers that are characterized by increased production of } \\
\text { reactive oxygen species. } \\
\text { (Myrcene, Limonene, Linalool, } \alpha \text {-terpineol, } \alpha \text {-Humulene, Ocimene) }\end{array}$ & $\begin{array}{l}\text { Antioxidant } \\
\text { Anticancer }\end{array}$ & {$[39,86-91]$} \\
\hline 5. & $\begin{array}{l}\text { Oral diseases such as gingivitis, periodontal disease, periodontitis } \\
\text { and salivary gland infections that are characterized by } \\
\text { bacterial-plaque build-up and bacterial infections. } \\
\text { (Ocimene, } \alpha \text {-terpineol, Linalool, } \alpha \text {-Pinene, Limonene) }\end{array}$ & Anti-microbial (anti-bacterial) & $\begin{array}{l}{[35,86-92,141,142]} \\
\text { (Cavaleiro et al., 2015) }\end{array}$ \\
\hline
\end{tabular}

\section{Conclusions and Future Direction}

Despite the vast anecdotal evidence of the use of cannabis and cannabinoids to treat oral and dental disorders, there is limited rigorous scientific evidence for the use of cannabinoids in dentistry. It should be noted, however, that there is generally strong evidence to support the wide therapeutic window and properties of cannabinoids, including, but not limited to their analgesic, antioxidant, anti-inflammatory, anti-microbial, anti-pruritic and anti-cancer properties. For these reasons, cannabinoids may have significant applicability in dentistry for the treatment of (1) toothaches, (2) bacterial infections causing periodontitis, gingivitis, periodontal disease, dental caries, salivary gland infections and abscesses, (3) inflammation-based oral diseases (4) oral and salivary gland cancers (5) Burning Mouth Syndrome, (6) dental anxiety, and (7) for general maintenance of oral hygiene. In addition to their wide therapeutic window, cannabinoids may also be a safer alternative to conventional, synthetic drugs used to treat oral and dental diseases, and commercial oral and dental products, in general.

In order for cannabinoids and cannabinoid-based products to become mainstay in conventional dentistry, further rigorous scientific studies are required to confirm their safety, tolerability, toxicity, efficacy, optimal dosages and optimal delivery systems in the 
treatment of oral and dental diseases. It is only until then that we will begin to see the regulatory framework governing these compounds and their use thereof, as defined by the U.S. Food and Drug Administration, become more accepting. This includes further studies into elucidating the specific mechanisms of action of secondary metabolites of $C$. sativa L. in various oral and dental diseases, and in the case of dental caries, elucidating the minimum inhibitory concentration (MIC), minimum bactericidal concentration (MBC), and the half maximal inhibitory concentration $\left(\mathrm{IC}_{50}\right)$ values of each cannabinoid-based pharmaceutical against causative agents of dental caries.

Patients should seek professional medical advice before using cannabinoid-based oral products.

Author Contributions: Conceptualization, H.L. and B.S.; Writing-Review and Editing, H.L., B.S., J.B., N.T., W.N. and K.N. All authors have read and agreed to the published version of the manuscript.

Funding: This research received no external funding.

Institutional Review Board Statement: Not applicable.

Informed Consent Statement: Not applicable.

Data Availability Statement: Data sharing is not applicable to this article. No new data were created or analyzed in this study.

Conflicts of Interest: The authors declare no conflict of interest.

Sample Availability: Samples of the compounds are not available from the authors.

\section{References}

1. Righolt, A.J.; Jevdjevic, M.; Marcenes, W.; Listl, S. Global-, Regional-, and Country-Level Economic Impacts of Dental Diseases in 2015. J. Dent. Res. 2018, 97, 501-507. [CrossRef] [PubMed]

2. Robinson, S. Jamaica's Oral Cancer Mortality Rate Is Nearly 100\%. Jamaica Observer, 1 April 2017. Available online: https: //www.jamaicaobserver.com/news/Jamaica-s-oral-cancer-mortality-rate-is-nearly-100-_94348 (accessed on 2 April 2021).

3. Listl, S.; Galloway, J.; Mossey, P.A.; Marcenes, W. Global Economic Impact of Dental Diseases. J. Dent. Res. 2015, 94, $1355-1361$. [CrossRef] [PubMed]

4. James, S.L.; Abate, D.; Abate, K.H.; Abay, S.M.; Abbafati, C.; Abbasi, N.; Abbastabar, H.; Abd-Allah, F.; Abdela, J.; Abdelalim, A.; et al. Global, regional, and national incidence, prevalence, and years lived with disability for 354 Diseases and Injuries for 195 countries and territories, 1990-2017: A systematic analysis for the Global Burden of Disease Study 2017. Lancet 2018, 392, 1789-1858. [CrossRef]

5. Botelho, J.; Proença, L.; Leira, Y.; Chambrone, L.; Mendes, J.J.; Machado, V. Economic burden of periodontal disease in Europe and the United states of America-An updated forecast. medRxiv 2021. [CrossRef]

6. World Health Organization. Oral Health. Available online: https://www.who.int/news-room/fact-sheets/detail/oral-health (accessed on 2 April 2021).

7. Kassebaum, N.J.; Bernabé, E.; Dahiya, M.; Bhandari, B.; Murray, C.J.L.; Marcenes, W. Global burden of severe periodontitis in 1990-2010: A systematic review and meta-regression. J. Dent. Res. 2014, 93, 1045-1053. [CrossRef] [PubMed]

8. Nazir, M.; Al-Ansari, A.; Al-Khalifa, K.; Alhareky, M.; Gaffar, B.; Almas, K. Global Prevalence of Periodontal Disease and Lack of Its Surveillance. Sci. World J. 2020, 2020, 2146160. [CrossRef] [PubMed]

9. GBD 2016 Disease and Injury Incidence and Prevalence Collaborators. Global, regional, and national incidence, prevalence, and years lived with disability for 328 diseases and injuries for 195 countries, 1990-2016: A systematic analysis for the Global Burden of Disease Study 2016. Lancet (Lond. Engl.) 2017, 390, 1211-1259. [CrossRef]

10. Petti, S.; Glendor, U.; Andersson, L. World traumatic dental injury prevalence and incidence, a meta-analysis-One billion living people have had traumatic dental injuries. Dent. Traumatol. Off. Publ. Int. Assoc. Dent. Traumatol. 2018, 34, 71-86. [CrossRef]

11. Zheng, L.W.; Hua, H.; Cheung, L.K. Traditional Chinese medicine and oral diseases: Today and tomorrow. Oral Dis. 2011, 17, 7-12. [CrossRef]

12. Meyer-Hamme, G.; Beckmann, K.; Radtke, J.; Efferth, T.; Greten, H.J.; Rostock, M.; Schröder, S. A survey of chinese medicinal herbal treatment for chemotherapy-induced oral mucositis. Evid.-Based Complement. Altern. Med. 2013, 2013, 284959. [CrossRef]

13. Agbor, A.M.; Naidoo, S. A review of the role of African traditional medicine in the management of oral diseases. Afr. J. Tradit. Complement. Altern. Med. 2016, 13, 133. [CrossRef]

14. Ayyanar, M.; Ignacimuthu, S. Herbal medicines for wound healing among tribal people in Southern India: Ethnobotanical and Scientific evidences. Int. J. Appl. Res. Nat. Prod. 2009, 2, $29-42$.

15. Shah, N.C. Herbal folk medicines in Northern India. J. Ethnopharmacol. 1982, 6, 293-301. [CrossRef]

16. Ganesan, A. The impact of natural products upon modern drug discovery. Curr. Opin. Chem. Biol. 2008, 12, 306-317. [CrossRef] 
17. Megersa, M.; Jima, T.T.; Goro, K.K. The Use of Medicinal Plants for the Treatment of Toothache in Ethiopia. Evid.-Based Complement. Altern. Med. 2019, 2019, 2645174. [CrossRef]

18. Debbarma, M.; Pala, N.A.; Kumar, M.; Bussmann, R.W. TRADITIONAL KNOWLEDGE OF MEDICINAL PLANTS IN TRIBES OF TRIPURA IN NORTHEAST, INDIA. Afr. J. Tradit. Complement. Altern. Med. AJTCAM 2017, 14, 156-168. [CrossRef]

19. Batiha, G.E.; Alkazmi, L.M.; Wasef, L.G.; Beshbishy, A.M.; Nadwa, E.H.; Rashwan, E.K. Syzygium aromaticum L. (Myrtaceae): Traditional Uses, Bioactive Chemical Constituents, Pharmacological and Toxicological Activities. Biomolecules 2020, 10, 202. [CrossRef]

20. Beyi, M.W. Ethnobotanical investigation of traditional medicinal plants in Dugda District, Oromia Region. SM J. Med. Plant Stud. 2018, 2, 1-19. [CrossRef]

21. Kefalew, A.; Asfaw, Z.; Kelbessa, E. Ethnobotany of medicinal plants in Ada'a District, East Shewa Zone of Oromia Regional State, Ethiopia. J. Ethnobiol. Ethnomed. 2015, 11, 25. [CrossRef]

22. Kidane, L.; Gebremedhin, G.; Beyene, T. Ethnobotanical study of medicinal plants in Ganta Afeshum District, Eastern Zone of Tigray, Northern Ethiopia. J. Ethnobiol. Ethnomed. 2018, 14, 64. [CrossRef]

23. George, D.; Bhat, S.S.; Antony, B. Comparative evaluation of the antimicrobial efficacy of aloe vera tooth gel and two popular commercial toothpastes: An in vitro study. Gen. Dent. 2009, 57, 238-241. [PubMed]

24. Al-Timimi, E.A.; Al-Casey, M. Effect of thymus vulgaris extract on streptococci and mutans streptococci, in comparison to chlorhexidine gluconate (in vivo study). J. Baghdad Coll. Dent. 2012, 24, 122-127.

25. Xu, J.S.; Li, Y.; Cao, X.; Cui, Y. The effect of eugenol on the cariogenic properties of Streptococcus mutans and dental caries development in rats. Exp. Ther. Med. 2013, 5, 1667-1670. [CrossRef] [PubMed]

26. Kumar, G.; Jalaluddin, M.; Rout, P.; Mohanty, R.; Dileep, C.L. Emerging trends of herbal care in dentistry. J. Clin. Diagn. Res. JCDR 2013, 7, 1827-1829. [CrossRef]

27. Elikkottil, J.; Gupta, P.; Gupta, K. The analgesic potential of cannabinoids. J. Opioid Manag. 2009, 5, 341-357. [CrossRef]

28. Mikuriya, T.H. Marijuana in medicine: Past, present and future. Calif. Med. 1969, 110, 34-40.

29. Zuardi, A.W. History of cannabis as a medicine: A review. Revista Brasileira de Psiquiatria (Sao Paulo, Brazil: 1999) 2006, $28,153-157$. [CrossRef]

30. Radwan, M.M.; Ross, S.A.; Slade, D.; Ahmed, S.A.; Zulfiqar, F.; Elsohly, M.A. Isolation and characterization of new Cannabis constituents from a high potency variety. Planta Med. 2008, 74, 267-272. [CrossRef]

31. Radwan, M.M.; Elsohly, M.A.; Slade, D.; Ahmed, S.A.; Wilson, L.; El-Alfy, A.T.; Khan, I.A.; Ross, S.A. Non-cannabinoid constituents from a high potency Cannabis sativa variety. Phytochemistry 2008, 69, 2627-2633. [CrossRef]

32. Radwan, M.M.; Elsohly, M.A.; Slade, D.; Ahmed, S.A.; Khan, I.A.; Ross, S.A. Biologically active cannabinoids from high-potency Cannabis sativa. J. Nat. Prod. 2009, 72, 906-911. [CrossRef]

33. Barrett, M.L.; Gordon, D.; Evans, F.J. Isolation from Cannabis sativa L. of cannflavin-A novel inhibitor of prostaglandin production. Biochem. Pharmacol. 1985, 34, 2019-2024. [CrossRef]

34. Elsohly, M.A.; Slade, D. Chemical constituents of marijuana: The complex mixture of natural cannabinoids. Life Sci. 2005, 78, 539-548. [CrossRef]

35. Pertwee, R.G.; McPartland, J.M.; Russo, E.B. Non-Phytocannabinoid constituents of cannabis and Herbal Synergy. In Handbook of Cannabis, 1st ed.; Pertwee, R.G., Ed.; Oxford University Press: Oxford, UK, 2014; Volume 1, pp. $280-295$.

36. Flores-Sanchez, I.J.; Verpoorte, R. PKS activities and biosynthesis of cannabinoids and flavonoids in Cannabis sativa L. plants. Plant Cell Physiol. 2008, 49, 1767-1782. [CrossRef]

37. Booth, J.K.; Page, J.E.; Bohlmann, J. Terpene synthases from Cannabis sativa. PLoS ONE 2017, 12, e0173911. [CrossRef]

38. Rea, K.A.; Casaretto, J.A.; Al-Abdul-Wahid, M.S.; Sukumaran, A.; Geddes-McAlister, J.; Rothstein, S.J.; Akhtar, T.A. Biosynthesis of cannflavins A and B from Cannabis sativa L. Phytochemistry 2019, 164, 162-171. [CrossRef]

39. Tomko, A.M.; Whynot, E.G.; Ellis, L.D.; Dupré, D.J. Anti-Cancer Potential of Cannabinoids, Terpenes, and Flavonoids Present in Cannabis. Cancers 2020, 12, 1985. [CrossRef]

40. Allaker, R.P.; Douglas, C.W. Novel anti-microbial therapies for dental plaque-related diseases. Int. J. Antimicrob. Agents 2009, 33, 8-13. [CrossRef]

41. Cannabidiol360. How Effective Is CBD for Dental Pain? 6 September 2018. Available online: https://cannabidiol360.com/cbdfor-dental-pain/ (accessed on 2 April 2021).

42. Ward, A. CBD Toothpaste Sounds Like a Good Idea but Lacks Conclusive Studies Proving It Is, 3 June 2019. Available online: https: / / www.greenentrepreneur.com/article/334497 (accessed on 2 April 2021).

43. Sanger, B. New Cannabis Toothpaste Has People Losing Their Minds. 12 August 2019. Available online: https://herb.co/news/ health/cannabis-toothpaste/ (accessed on 3 April 2021).

44. Kaufman, H. 5 Benefits of UTILIZING CBD Oral Care. 19 May 2020. Available online: https://www.americanspa.com/cbd/5benefits-utilizing-cbd-oral-care (accessed on 3 April 2021).

45. Bourque, A. Cannabis for Your Mouth: R\&d, Patents, and Your Next Visit to the Dentist. 29 June 2019. Available online: https:/ /www.forbes.com/sites/andrebourque/2019/06/29/cannabis-for-your-mouth-rd-patents-and-your-next-visitto-the-dentist/?sh=6ae0d25a30fb (accessed on 3 April 2021).

46. Stahl, V.; Vasudevan, K. Comparison of Efficacy of Cannabinoids versus Commercial Oral Care Products in Reducing Bacterial Content from Dental Plaque: A Preliminary Observation. Cureus 2020, 12, e6809. [CrossRef] 
47. Vasudevan, K.; Stahl, V. Cannabinoids infused mouthwash products are as effective as chlorhexidine on inhibition of totalculturable bacterial content in dental plaque samples. J. Cannabis Res. 2020, 2, 20. [CrossRef]

48. Stahl, V. Cannabis and Derivatives Thereof for the Treatment of Pain and Inflammation Related with Dental Pulp and Bone Regeneration Related to Dental Jaw Bone Defects. U.S. Patent No. US20200222361A1, 12 November 2020.

49. Anastassov, G.; Changoer, L. Oral Care Composition Comprising Cannabinoids. U.S. Patent No. US10172786B2, 8 January 2019.

50. 마진열, 임남희, 정윤희, 이주혜, 이지혜, 김 홍 익, 유기종. Composition for Prevention or Treatment of Dental Caries Comprising Extract of Cannabis sativa. South Korea Patent No. KR20120133135A, 10 December 2012.

51. Van Damme, P.A.; Anastassov, G.E.; Lekhram, C. Chewing Gum Compositions Comprising Cannabinoids. U.S. Patent No. EP2280687B1, 27 February 2019.

52. Di Marzo, V. The endocannabinoid system: Its general strategy of action, tools for its pharmacological manipulation and potential therapeutic exploitation. Pharmacol. Res. 2009, 60,77-84. [CrossRef]

53. Silver, R.J. The Endocannabinoid System of Animals. Animals 2019, 9, 686. [CrossRef] [PubMed]

54. Pagotto, U.; Marsicano, G.; Cota, D.; Lutz, B.; Pasquali, R. The emerging role of the endocannabinoid system in endocrine regulation and energy balance. Endocr. Rev. 2006, 27, 73-100. [CrossRef] [PubMed]

55. Marsicano, G.; Lafenêtre, P. Roles of the endocannabinoid system in learning and memory. Curr. Top. Behav. Neurosci. 2009, 1, 201-230. [CrossRef] [PubMed]

56. Bermudez-Silva, F.J.; Cardinal, P.; Cota, D. The role of the endocannabinoid system in the neuroendocrine regulation of energy balance. J. Psychopharmacol. (Oxf. Engl.) 2012, 26, 114-124. [CrossRef]

57. Woodhams, S.G.; Sagar, D.R.; Burston, J.J.; Chapman, V. The role of the endocannabinoid system in pain. Handb. Exp. Pharmacol. 2015, 227, 119-143. [CrossRef]

58. Guindon, J.; Hohmann, A.G. The endocannabinoid system and pain. CNS Neurol. Disord. Drug Targets 2009, 8, 403-421. [CrossRef]

59. Gamage, T.F.; Lichtman, A.H. The endocannabinoid system: Role in energy regulation. Pediatr. Blood Cancer 2012, 58, 144-148. [CrossRef]

60. Karasu, T.; Marczylo, T.H.; Maccarrone, M.; Konje, J.C. The role of sex steroid hormones, cytokines and the endocannabinoid system in female fertility. Hum. Reprod. Update 2011, 17, 347-361. [CrossRef]

61. Walker, O.S.; Holloway, A.C.; Raha, S. The role of the endocannabinoid system in female reproductive tissues. J. Ovarian Res. 2019, 12, 3. [CrossRef]

62. Taylor, A.H.; Ang, C.; Bell, S.C.; Konje, J.C. The role of the endocannabinoid system in gametogenesis, implantation and early pregnancy. Hum. Reprod. Update 2007, 13, 501-513. [CrossRef]

63. Pacher, P.; Steffens, S. The emerging role of the endocannabinoid system in cardiovascular disease. Semin. Immunopathol. 2009, 31, 63-77. [CrossRef]

64. Manzanares, J.; Cabañero, D.; Puente, N.; García-Gutiérrez, M.S.; Grandes, P.; Maldonado, R. Role of the endocannabinoid system in drug addiction. Biochem. Pharmacol. 2018, 157, 108-121. [CrossRef]

65. Parolaro, D.; Realini, N.; Vigano, D.; Guidali, C.; Rubino, T. The endocannabinoid system and psychiatric disorders. Exp. Neurol. 2010, 224, 3-14. [CrossRef]

66. Vinod, K.Y.; Hungund, B.L. Role of the endocannabinoid system in depression and suicide. Trends Pharmacol. Sci. 2006, 27, 539-545. [CrossRef]

67. Fakhoury, M. Role of the Endocannabinoid System in the Pathophysiology of Schizophrenia. Mol. Neurobiol. 2017, 54, 768-778. [CrossRef]

68. Pazos, M.R.; Núñez, E.; Benito, C.; Tolón, R.M.; Romero, J. Role of the endocannabinoid system in Alzheimer's disease: New perspectives. Life Sci. 2004, 75, 1907-1915. [CrossRef]

69. André, A.; Gonthier, M.P. The endocannabinoid system: Its roles in energy balance and potential as a target for obesity treatment. Int. J. Biochem. Cell Biol. 2010, 42, 1788-1801. [CrossRef]

70. Serra, G.; Fratta, W. A possible role for the endocannabinoid system in the neurobiology of depression. Clin. Pract. Epidemiol. Ment. Health CP EMH 2007, 3, 25. [CrossRef]

71. Zou, S.; Kumar, U. Cannabinoid Receptors and the Endocannabinoid System: Signaling and Function in the Central Nervous System. Int. J. Mol. Sci. 2018, 19, 833. [CrossRef]

72. Zou, M.; Li, D.; Li, L.; Wu, L.; Sun, C. Role of the endocannabinoid system in neurological disorders. Int. J. Dev. Neurosci. Off. J. Int. Soc. Dev. Neurosci. 2019, 76, 95-102. [CrossRef]

73. Gruden, G.; Barutta, F.; Kunos, G.; Pacher, P. Role of the endocannabinoid system in diabetes and diabetic complications. Br. J. Pharmacol. 2016, 173, 1116-1127. [CrossRef]

74. Pisanti, S.; Picardi, P.; D'Alessandro, A.; Laezza, C.; Bifulco, M. The endocannabinoid signaling system in cancer. Trends Pharmacol. Sci. 2013, 34, 273-282. [CrossRef]

75. Di Marzo, V. New approaches and challenges to targeting the endocannabinoid system. Nat. Rev. Drug Discov. 2018, 17, 623-639. [CrossRef]

76. Alhouayek, M.; Boldrup, L.; Fowler, C.J. Altered mRNA Expression of Genes Involved in Endocannabinoid Signaling in Squamous Cell Carcinoma of the Oral Tongue. Cancer Investig. 2019, 37, 327-338. [CrossRef]

77. Mandal, D.A. Phytocannabinoids. 26 February 2019. Available online: https://www.news-medical.net/health/Phytocannabinoids. aspx (accessed on 2 April 2021). 
78. Andre, C.M.; Hausman, J.F.; Guerriero, G. Cannabis sativa: The Plant of the Thousand and One Molecules. Front. Plant Sci. 2016, 7, 19. [CrossRef]

79. ElSohly, M.A.; Radwan, M.M.; Gul, W.; Chandra, S.; Galal, A. Phytochemistry of Cannabis sativa L. Prog. Chem. Org. Nat. Prod. 2017, 103, 1-36. [CrossRef]

80. Demain, A.L.; Fang, A. The natural functions of secondary metabolites. Adv. Biochem. Eng./Biotechnol. 2000, 69, 1-39. [CrossRef]

81. Earlenbaugh, E. What Are FLAVONOIDS? 11 March 2021. Available online: https:// cannigma.com/plant/what-are-cannabisflavonoids / (accessed on 2 April 2021).

82. Bennett, P. What Are Cannabis Flavonoids and What Do They Do? 9 February 2018. Available online: https://www.leafly.com/ news / cannabis-101/what-are-marijuana-flavonoids (accessed on 3 April 2021).

83. Rahn, B. What Are Cannabis Terpenes and What Do They Do? 18 November 2019. Available online: https://www.leafly.com/ news / cannabis-101/terpenes-the-flavors-of-cannabis-aromatherapy (accessed on 3 April 2021).

84. Appendino, G.; Gibbons, S.; Giana, A.; Pagani, A.; Grassi, G.; Stavri, M.; Smith, E.; Rahman, M.M. Antibacterial cannabinoids from Cannabis sativa: A structure-activity study. J. Nat. Prod. 2008, 71, 1427-1430. [CrossRef]

85. Rao, V.S.; Menezes, A.M.; Viana, G.S. Effect of myrcene on nociception in mice. J. Pharm. Pharmacol. 1990, 42, 877-878. [CrossRef]

86. Johnson, J.; Theisen, E. What Are Terpenes? 6 March 2020. Available online: https://www.medicalnewstoday.com/articles/ what-are-terpenes (accessed on 28 July 2020).

87. Valente, J.; Zuzarte, M.; Gonçalves, M.J.; Lopes, M.C.; Cavaleiro, C.; Salgueiro, L.; Cruz, M.T. Antifungal, antioxidant and anti-inflammatory activities of Oenanthe crocata L. essential oil. Food Chem. Toxicol. Int. J. Publ. Br. Indus. Biol. Res. Assoc. 2013, 62, 349-354. [CrossRef]

88. Cavaleiro, C.; Salgueiro, L.; Gonçalves, M.J.; Hrimpeng, K.; Pinto, J.; Pinto, E. Antifungal activity of the essential oil of Angelica major against Candida, Cryptococcus, Aspergillus and dermatophyte species. J. Nat. Med. 2015, 69, 241-248. [CrossRef] [PubMed]

89. Golfakhrabadi, F.; Khanavi, M.; Ostad, S.N.; Saeidnia, S.; Vatandoost, H.; Abai, M.R.; Hafizi, M.; Yousefbeyk, F.; Rad, Y.R.; Baghenegadian, A.; et al. Biological activities and composition of ferulago carduchorum essential Oil. J. Arthropod. Borne Dis. 2014, 9, 104-115.

90. Kim, M.J.; Yang, K.W.; Kim, S.S.; Park, S.M.; Park, K.J.; Kim, K.S.; Choi, Y.H.; Cho, K.K.; Hyun, C.G. Chemical composition and anti-inflammation activity of essential oils from Citrus unshiu flower. Nat. Prod. Comm. 2014, 9, 727-730. [CrossRef]

91. Loizzo, M.R.; Saab, A.M.; Tundis, R.; Statti, G.A.; Menichini, F.; Lampronti, I.; Gambari, R.; Cinatl, J.; Doerr, H.W. Phytochemical analysis and in vitro antiviral activities of the essential oils of seven Lebanon species. Chem. Biodiver. 2008, 5, 461-470. [CrossRef] [PubMed]

92. Vieira-Brock, P.L.; Vaughan, B.M.; Vollmer, D.L. Comparison of antimicrobial activities of natural essential oils and synthetic fragrances against selected environmental pathogens. Biochim. Open 2017, 5, 8-13. [CrossRef] [PubMed]

93. ElSohly, H.N.; Turner, C.E.; Clark, A.M.; ElSohly, M.A. Synthesis and antimicrobial activities of certain cannabichromene and cannabigerol related compounds. J. Pharm. Sci. 1982, 71, 1319-1323. [CrossRef] [PubMed]

94. Klahn, P. Cannabinoids-Promising Antimicrobial Drugs orIntoxicants with Benefits? Antibiotics 2020, 9, 297. [CrossRef] [PubMed]

95. Baron, E.P. Medicinal Properties of Cannabinoids, Terpenes, and Flavonoids in Cannabis, and Benefits in Migraine, Headache, and Pain: An Update on Current Evidence and Cannabis Science. Headache 2018, 58, 1139-1186. [CrossRef]

96. Russo, E.B. The Case for the Entourage Effect and Conventional Breeding of Clinical Cannabis: No "Strain," No Gain. Front. Plant Sci. 2019, 9, 1969. [CrossRef]

97. Koltai, H.; Namdar, D. Cannabis Phytomolecule 'Entourage': From Domestication to Medical Use. Trends Plant Sci. 2020, 25, 976-984. [CrossRef]

98. Pellati, F.; Borgonetti, V.; Brighenti, V.; Biagi, M.; Benvenuti, S.; Corsi, L. Cannabis sativa L. and Nonpsychoactive Cannabinoids: Their Chemistry and Role against Oxidative Stress, Inflammation, and Cancer. BioMed Res. Int. 2018, 2018, 1691428. [CrossRef]

99. Velasco, G.; Sánchez, C.; Guzmán, M. Anticancer mechanisms of cannabinoids. Curr. Oncol. 2016, 23, S23-S32. [CrossRef]

100. Velasco, G.; Hernández-Tiedra, S.; Dávila, D.; Lorente, M. The use of cannabinoids as anticancer agents. Prog. NeuroPsychopharmacol. Biol. Psychiatry 2016, 64, 259-266. [CrossRef]

101. Guzmán, M. Cannabinoids: Potential anticancer agents. Nat. Rev. Cancer 2003, 3, 745-755. [CrossRef]

102. Velasco, G.; Sánchez, C.; Guzmán, M. Towards the use of cannabinoids as antitumour agents. Nat. Rev. Cancer 2012, 12, 436-444. [CrossRef] [PubMed]

103. Ramer, R.; Hinz, B. Cannabinoids as Anticancer Drugs. Adv. Pharmacol. (San Diego Calif.) 2017, 80, 397-436. [CrossRef]

104. Nagarkatti, P.; Pandey, R.; Rieder, S.A.; Hegde, V.L.; Nagarkatti, M. Cannabinoids as novel anti-inflammatory drugs. Future Med. Chem. 2009, 1, 1333-1349. [CrossRef]

105. Zurier, R.B. Prospects for cannabinoids as anti-inflammatory agents. J. Cell. Biochem. 2003, 88, 462-466. [CrossRef]

106. Atalay, S.; Jarocka-Karpowicz, I.; Skrzydlewska, E. Antioxidative and Anti-Inflammatory Properties of Cannabidiol. Antioxidants 2019, 9, 21. [CrossRef] [PubMed]

107. Costa, B.; Trovato, A.E.; Comelli, F.; Giagnoni, G.; Colleoni, M. The non-psychoactive cannabis constituent cannabidiol is an orally effective therapeutic agent in rat chronic inflammatory and neuropathic pain. Eur. J. Pharmacol. 2007, 556, 75-83. [CrossRef]

108. Blaskovich, M.A.T.; Kavanagh, A.M.; Elliott, A.G.; Zhang, B.; Ramu, S.; Amado, M.; Lowe, G.J.; Hinton, A.O.; Zuegg, J.; Beare, N.; et al. The antimicrobial potential of cannabidiol. Commun. Biol. 2021, 4, 7. [CrossRef] [PubMed] 
109. Mechoulam, R.; Peters, M.; Murillo-Rodriguez, E.; Hanus, L.O. Cannabidiol-Recent advances. Chem. Biodivers. 2007, 4, 1678-1692. [CrossRef]

110. Petrosino, S.; Verde, R.; Vaia, M.; Allarà, M.; Iuvone, T.; Di Marzo, V. Anti-inflammatory Properties of Cannabidiol, a Nonpsychotropic Cannabinoid, in Experimental Allergic Contact Dermatitis. J. Pharmacol. Exp. Ther. 2018, 365, 652-663. [CrossRef]

111. Izzo, A.A.; Capasso, R.; Aviello, G.; Borrelli, F.; Romano, B.; Piscitelli, F.; Gallo, L.; Capasso, F.; Orlando, P.; Di Marzo, V. Inhibitory effect of cannabichromene, a major non-psychotropic cannabinoid extracted from Cannabis sativa, on inflammation-induced hypermotility in mice. Br. J. Pharmacol. 2012, 166, 1444-1460. [CrossRef]

112. Davis, W.M.; Hatoum, N.S. Neurobehavioral actions of cannabichromene and interactions with delta 9-tetrahydrocannabinol. Gen. Pharmacol. 1983, 14, 247-252. [CrossRef]

113. Turner, C.E.; Elsohly, M.A. Biological activity of cannabichromene, its homologs and isomers. J. Clin. Pharmacol. 1981, 21, 283S-291S. [CrossRef]

114. DeLong, G.T.; Wolf, C.E.; Poklis, A.; Lichtman, A.H. Pharmacological evaluation of the natural constituent of Cannabis sativa, cannabichromene and its modulation by $\Delta(9)$-tetrahydrocannabinol. Drug Alcohol Depend. 2010, 112, 126-133. [CrossRef]

115. Wirth, P.W.; Watson, E.S.; ElSohly, M.; Turner, C.E.; Murphy, J.C. Anti-inflammatory properties of cannabichromene. Life Sci. 1980, 26, 1991-1995. [CrossRef]

116. Lygos CBX Adds Cannabichromene to Its Growing Portfolio of High-Quality, Pure and SUSTAINABLE Cannabinoids.19 January 2021. Available online: https://lygos.com/lygos-cbx-adds-cannabichromene-to-its-growing-portfolio-of-high-quality-pureand-sustainable-cannabinoids / (accessed on 3 April 2021).

117. Nachnani, R.; Raup-Konsavage, W.M.; Vrana, K.E. The Pharmacological Case for Cannabigerol. J. Pharmacol. Exp. Ther. 2021, 376, 204-212. [CrossRef]

118. Farha, M.A.; El-Halfawy, O.M.; Gale, R.T.; MacNair, C.R.; Carfrae, L.A.; Zhang, X.; Jentsch, N.G.; Magolan, J.; Brown, E.D. Uncovering the Hidden Antibiotic Potential of Cannabis. ACS Infect. Dis. 2020, 6, 338-346. [CrossRef]

119. Di Giacomo, V.; Chiavaroli, A.; Recinella, L.; Orlando, G.; Cataldi, A.; Rapino, M.; Di Valerio, V.; Ronci, M.; Leone, S.; Brunetti, L.; et al. Antioxidant and Neuroprotective Effects Induced by Cannabidiol and Cannabigerol in Rat CTX-TNA2 Astrocytes and Isolated Cortexes. Int. J. Mol. Sci. 2020, 21, 3575. [CrossRef]

120. Marsicano, G.; Moosmann, B.; Hermann, H.; Lutz, B.; Behl, C. Neuroprotective properties of cannabinoids against oxidative stress: Role of the cannabinoid receptor CB1. J. Neurochem. 2002, 80, 448-456. [CrossRef]

121. Stone, N.L.; Murphy, A.J.; England, T.J.; O'Sullivan, S.E. A systematic review of minor phytocannabinoids with promising neuroprotective potential. Br. J. Pharmacol. 2020, 177, 4330-4352. [CrossRef]

122. Nuutinen, T. Medicinal properties of terpenes found in Cannabis sativa and Humulus lupulus. Eur. J. Med. Chem. 2018, 157, 198-228. [CrossRef]

123. Salehi, B.; Upadhyay, S.; Erdogan Orhan, I.; Kumar Jugran, A.; Jayaweera, S.L.D.; Dias, D.A.; Sharopov, F.; Taheri, Y.; Martins, N.; Baghalpour, N.; et al. Therapeutic Potential of $\alpha$ - and $\beta$-Pinene: A Miracle Gift of Nature. Biomolecules 2019, 9, 738. [CrossRef]

124. Karas, J.A.; Wong, L.; Paulin, O.; Mazeh, A.C.; Hussein, M.H.; Li, J.; Velkov, T. The Antimicrobial Activity of Cannabinoids. Antibiotics 2020, 9, 406. [CrossRef]

125. Iseppi, R.; Brighenti, V.; Licata, M.; Lambertini, A.; Sabia, C.; Messi, P.; Pellati, F.; Benvenuti, S. Chemical Characterization and Evaluation of the Antibacterial Activity of Essential Oils from Fibre-Type Cannabis sativa L. (Hemp). Molecules 2019, $24,2302$. [CrossRef]

126. Gallily, R.; Yekhtin, Z.; Hanuš, L.O. The Anti-Inflammatory Properties of Terpenoids from Cannabis. Cannabis Cannabinoid Res. 2018, 3, 282-290. [CrossRef]

127. Rogerio, A.P.; Andrade, E.L.; Leite, D.F.; Figueiredo, C.P.; Calixto, J.B. Preventive and therapeutic anti-inflammatory properties of the sesquiterpene alpha-humulene in experimental airways allergic inflammation. Br. J. Pharmacol. 2009, 158, 1074-1087. [CrossRef] [PubMed]

128. Chaves, J.S.; Leal, P.C.; Pianowisky, L.; Calixto, J.B. Pharmacokinetics and tissue distribution of the sesquiterpene alpha-humulene in mice. Planta Med. 2008, 74, 1678-1683. [CrossRef] [PubMed]

129. Satsu, H.; Matsuda, T.; Toshimitsu, T.; Mori, A.; Mae, T.; Tsukagawa, M.; Kitahara, M.; Shimizu, M. Regulation of interleukin-8 secretion in human intestinal epithelial Caco-2 cells by alpha-humulene. BioFactors (Oxf. Engl.) 2004, 21, 137-139. [CrossRef] [PubMed]

130. Legault, J.; Pichette, A. Potentiating effect of beta-caryophyllene on anticancer activity of alpha-humulene, isocaryophyllene and paclitaxel. J. Pharm. Pharmacol. 2007, 59, 1643-1647. [CrossRef] [PubMed]

131. Bouajaj, S.; Benyamna, A.; Bouamama, H.; Romane, A.; Falconieri, D.; Piras, A.; Marongiu, B. Antibacterial, allelopathic and antioxidant activities of essential oil of Salvia officinalis L. growing wild in the Atlas Mountains of Morocco. Nat. Prod. Res. 2013, 27, 1673-1676. [CrossRef] [PubMed]

132. Dahham, S.S.; Tabana, Y.M.; Iqbal, M.A.; Ahamed, M.B.; Ezzat, M.O.; Majid, A.S.; Majid, A.M. The Anticancer, Antioxidant and Antimicrobial Properties of the Sesquiterpene $\beta$-Caryophyllene from the Essential Oil of Aquilaria crassna. Molecules 2015, 20, 11808-11829. [CrossRef] [PubMed]

133. Pieri, F.A.; Souza, M.C.; Vermelho, L.L.; Vermelho, M.L.; Perciano, P.G.; Vargas, F.S.; Borges, A.P.; da Veiga-Junior, V.F.; Moreira, M.A. Use of $\beta$-caryophyllene to combat bacterial dental plaque formation in dogs. BMC Vet. Res. 2016, 12, 216. [CrossRef] 
134. Hanuš, L.O.; Hod, Y. Terpenes/Terpenoids in Cannabis: Are They Important? Med. Cannabis Cannabinoids 2020, 3, 25-60. [CrossRef]

135. Zahi, M.R.; El Hattab, M.; Liang, H.; Yuan, Q. Enhancing the antimicrobial activity of d-limonene nanoemulsion with the inclusion of $\varepsilon$-polylysine. Food Chem. 2017, 221, 18-23. [CrossRef]

136. Han, Y.; Sun, Z.; Chen, W. Antimicrobial Susceptibility and Antibacterial Mechanism of Limonene against Listeria monocytogenes. Molecules 2019, 25, 33. [CrossRef]

137. Espina, L.; Gelaw, T.K.; de Lamo-Castellví, S.; Pagán, R.; García-Gonzalo, D. Mechanism of bacterial inactivation by (+)-limonene and its potential use in food preservation combined processes. PLoS ONE 2013, 8, e56769. [CrossRef]

138. Lima, N.G.; De Sousa, D.P.; Pimenta, F.C.; Alves, M.F.; De Souza, F.S.; Macedo, R.O.; Cardoso, R.B.; de Morais, L.C.; Melo Diniz, M.; de Almeida, R.N. Anxiolytic-like activity and GC-MS analysis of (R)-(+)-limonene fragrance, a natural compound found in foods and plants. Pharmacol. Biochem. Behav. 2013, 103, 450-454. [CrossRef]

139. de Sousa, D.P. Analgesic-like activity of essential oils constituents. Molecules 2011, 16, 2233-2252. [CrossRef]

140. Roberto, D.; Micucci, P.; Sebastian, T.; Graciela, F.; Anesini, C. Antioxidant activity of limonene on normal murine lymphocytes: Relation to $\mathrm{H}_{2} \mathrm{O}_{2}$ modulation and cell proliferation. Basic Clin. Pharmacol. Toxicol. 2010, 106, 38-44. [CrossRef] [PubMed]

141. Held, S.; Schieberle, P.; Somoza, V. Characterization of $\alpha$-Terpineol as an anti-inflammatory component of orange juice by in vitro studies using oral buccal cells. J. Agric. Food Chem. 2007, 55, 8040-8046. [CrossRef] [PubMed]

142. Quintans-Júnior, L.J.; Oliveira, M.G.; Santana, M.F.; Santana, M.T.; Guimarães, A.G.; Siqueira, J.S.; Almeida, R.N. $\alpha$-Terpineol reduces nociceptive behavior in mice. Pharm. Biol. 2011, 49, 583-586. [CrossRef]

143. Forget Aspirin, These Marijuana-Based Painkillers Are 30 Times More Powerful. 26 July 2019. Available online: https://www. chicagotribune.com/marijuana/sns-tft-marijuana-based-painkillers-20190726-6hcou2ju7nacrcpnqfndyco7fe-story.html (accessed on 4 April 2021).

144. Cannabis CannaFlavins 30x Stronger Than Aspirin in Cell Experiment. 27 December 2019. Available online: https://www.rxleaf. com/cannaflavins-antiinflammation-pain-relief-cannabis-medicine/ (accessed on 4 April 2021).

145. Barrett, M.L.; Scutt, A.M.; Evans, F.J. Cannflavin A and B, prenylated flavones from Cannabis sativa L. Experientia 1986, $42,452-453$. [CrossRef]

146. Erridge, S.; Mangal, N.; Salazar, O.; Pacchetti, B.; Sodergren, M.H. Cannflavins-From plant to patient: A scoping review. Fitoterapia 2020, 146, 104712. [CrossRef]

147. Calignano, A.; La Rana, G.; Giuffrida, A.; Piomelli, D. Control of pain initiation by endogenous cannabinoids. Nature 1998, 394, 277-281. [CrossRef]

148. Pisanti, S.; Malfitano, A.M.; Grimaldi, C.; Santoro, A.; Gazzerro, P.; Laezza, C.; Bifulco, M. Use of cannabinoid receptor agonists in cancer therapy as palliative and curative agents. Best Pract. Res. Clin. Endocrinol. Metab. 2009, 23, 117-131. [CrossRef]

149. Conti, S.; Costa, B.; Colleoni, M.; Parolaro, D.; Giagnoni, G. Antiinflammatory action of endocannabinoid palmitoylethanolamide and the synthetic cannabinoid nabilone in a model of acute inflammation in the rat. Br. J. Pharmacol. 2002, 135, 181-187. [CrossRef]

150. Chakravarti, B.; Ravi, J.; Ganju, R.K. Cannabinoids as therapeutic agents in cancer: Current status and future implications. Oncotarget 2014, 5, 5852-5872. [CrossRef]

151. Sumariwalla, P.F.; Gallily, R.; Tchilibon, S.; Fride, E.; Mechoulam, R.; Feldmann, M. A novel synthetic, nonpsychoactive cannabinoid acid (HU-320) with antiinflammatory properties in murine collagen-induced arthritis. Arthritis Rheum. 2004, 50, 985-998. [CrossRef] [PubMed]

152. Xu, H.; Cheng, C.L.; Chen, M.; Manivannan, A.; Cabay, L.; Pertwee, R.G.; Coutts, A.; Forrester, J.V. Anti-inflammatory property of the cannabinoid receptor-2-selective agonist JWH-133 in a rodent model of autoimmune uveoretinitis. J. Leukoc. Biol. 2007, 82, 532-541. [CrossRef] [PubMed]

153. Yuill, M.B.; Hale, D.E.; Guindon, J.; Morgan, D.J. Anti-nociceptive interactions between opioids and a cannabinoid receptor 2 agonist in inflammatory pain. Mol. Pain 2017, 13, 1744806917728227. [CrossRef] [PubMed]

154. Müller, L.; Radtke, A.; Decker, J.; Koch, M.; Belge, G. The Synthetic Cannabinoid WIN 55,212-2 Elicits Death in Human Cancer Cell Lines. Anticancer Res. 2017, 37, 6341-6345. [CrossRef]

155. Roberto, D.; Klotz, L.H.; Venkateswaran, V. Cannabinoid WIN 55,212-2 induces cell cycle arrest and apoptosis, and inhibits proliferation, migration, invasion, and tumor growth in prostate cancer in a cannabinoid-receptor 2 dependent manner. Prostate 2019, 79, 151-159. [CrossRef]

156. Borsani, E.; Majorana, A.; Cocchi, M.A.; Conti, G.; Bonadeo, S.; Padovani, A.; Lauria, G.; Bardellini, E.; Rezzani, R.; Rodella, L.F. Epithelial expression of vanilloid and cannabinoid receptors: A potential role in burning mouth syndrome pathogenesis. Histol. Histopathol. 2014, 29, 523-533. [CrossRef]

157. Hipkaeo, W.; Watanabe, M.; Kondo, H. Localization of Cannabinoid Receptor 1 (CB1) in Submandibular and Sublingual Salivary Glands of Mice throughout Postnatal Development. Int. J. Morphol. 2015, 33, 695-700. [CrossRef]

158. Prestifilippo, J.P.; Fernández-Solari, J.; Cal, C.D.L.; Iribarne, M.; Suburo, A.M.; Rettori, V.; McCann, S.M.; Elverdin, J.C. Inhibition of Salivary Secretion by Activation of Cannabinoid Receptors. Exp. Biol. Med. 2006, 231, 1421-1429. [CrossRef]

159. Kopach, O.; Vats, J.; Netsyk, O.; Voitenko, N.; Irving, A.; Fedirko, N. Cannabinoid receptors in submandibular acinar cells: Functional coupling between saliva fluid and electrolytes secretion and $\mathrm{Ca}^{2+}$ signalling. J. Cell Sci. 2012, 125 Pt 8, $1884-1895$. [CrossRef] 
160. Kakoei, S.; Parirokh, M.; Nakhaee, N.; Jamshidshirazi, F.; Rad, M.; Kakooei, S. Prevalence of toothache and associated factors: A population-based study in Southeast Iran. Iran. Endod. J. 2013, 8, 123-128.

161. Cohen, L.A.; Bonito, A.J.; Akin, D.R.; Manski, R.J.; Macek, M.D.; Edwards, R.R.; Cornelius, L.J. Toothache pain: A comparison of visits to physicians, emergency departments and dentists. J. Am. Dent. Assoc. 2008, 139, 1205-1216. [CrossRef]

162. Vučković, S.; Srebro, D.; Vujović, K.S.; Vučetić, Č.; Prostran, M. Cannabinoids and Pain: New Insights From Old Molecules. Front. Pharmacol. 2018, 9, 1259. [CrossRef]

163. Royal Queen Seeds. Can CBD Help Relieve Toothache? 25 November 2019. Available online: https: / / www.royalqueenseeds. com/blog-can-cbd-help-relieve-toothache-n1062 (accessed on 6 April 2021).

164. Mayo Foundation for Medical Education and Research. Burning mouth syndrome. Mayo Clinic, 14 February 2019. Available online: https: / / www.mayoclinic.org/diseases-conditions/burning-mouth-syndrome/symptoms-causes/syc-20350911 (accessed on 6 April 2021).

165. Sun, A.; Wu, K.M.; Wang, Y.P.; Lin, H.P.; Chen, H.M.; Chiang, C.P. Burning mouth syndrome: A review and update. J. Oral Pathol. Med. Off. Publ. Int. Assoc. Oral Pathol. Am. Acad. Oral Pathol. 2013, 42, 649-655. [CrossRef]

166. Pereira, S.R.; Tello Velasquez, J.; Duggan, S.; Ivanisevic, B.; McKenna, J.P.; McCreary, C.; Downer, E.J. Recent advances in the understanding of the aetiology and therapeutic strategies in burning mouth syndrome: Focus on the actions of cannabinoids. Eur. J. Neurosci. 2020. [CrossRef]

167. Study: Cannabis Extracts Mitigate Symptoms of Burning Mouth Syndrome. NORML, 10 May 2021. Available online: https://norml.org/news/2020/11/05/study-cannabis-extracts-mitigate-symptoms-of-burning-mouth-syndrome/ (accessed on 6 April 2021).

168. Dowden, A. Cannabis Oil May Help Burning Mouth Syndrome. Labroots.com, 13 November 2020. Available online: https:/ www. labroots.com/trending/health-and-medicine/19161/cannabis-oil-help-burning-mouth-syndrome (accessed on 6 April 2021).

169. Gambino, A.; Cabras, M.; Panagiotakos, E.; Calvo, F.; Macciotta, A.; Cafaro, A.; Suria, M.; Haddad, G.E.; Broccoletti, R.; Arduino, P.G. Evaluating the Suitability and Potential Efficiency of Cannabis sativa Oil for Patients with Primary Burning Mouth Syndrome: A Prospective, Open-Label, Single-Arm Pilot Study. Pain Med. (Malden Mass.) 2021, 22, 142-151. [CrossRef]

170. Sunariani, J.; Wijaksana, I.K.E.; Setiawatie, E.M. The Role of Vanilloid and Cannabinoid Receptors in Taste and Pain Perception in Burning Mouth Syndrome. In Proceedings of the 7th International Meeting and the 4th Joint Scientific Meeting in Dentistry, Surabaya, Indonesia, 5-7 October 2017. [CrossRef]

171. Bare, L.C.; Dundes, L. Strategies for combating dental anxiety. J. Dent. Educ. 2004, 68, 1172-1177. [CrossRef]

172. Berggren, U.; Meynert, G. Dental fear and avoidance: Causes, symptoms, and consequences. J. Am. Dent. Assoc. 1984, 109, 247-251. [CrossRef]

173. Townend, E.; Dimigen, G.; Fung, D. A clinical study of child dental anxiety. Behav. Res. Ther. 2000, 38, 31-46. [CrossRef]

174. Minja, I.K.; Kahabuka, F.K. Dental Anxiety and Its Consequences to Oral Health Care Attendance and Delivery. Anxiety Disord. From Childhood Adulthood 2019. [CrossRef]

175. Cohen, S.M.; Fiske, J.; Newton, J.T. The impact of dental anxiety on daily living. Br. Dent. J. 2000, 189, 385-390. [CrossRef]

176. Hällström, T.; Halling, A. Prevalence of dentistry phobia and its relation to missing teeth, alveolar bone loss and dental care habits in an urban community sample. Acta Psychiatr. Scand. 1984, 70, 438-446. [CrossRef] [PubMed]

177. Locker, D.; Liddell, A. Clinical correlates of dental anxiety among older adults. Community Dent. Oral Epidemiol. 1992, 20, 372-375. [CrossRef]

178. Hakeberg, M.; Berggren, U.; Gröndahl, H.G. A radiographic study of dental health in adult patients with dental anxiety. Community Dent. Oral Epidemiol. 1993, 21, 27-30. [CrossRef]

179. Appukuttan, D.P. Strategies to manage patients with dental anxiety and dental phobia: Literature review. Clin. Cosmet. Investig. Dent. 2016, 8, 35-50. [CrossRef]

180. Sharif, M.O. Dental anxiety: Detection and management. J. Appl. Oral Sci. Rev. FOB 2010, 18. [CrossRef]

181. Wide Boman, U.; Carlsson, V.; Westin, M.; Hakeberg, M. Psychological treatment of dental anxiety among adults: A systematic review. Eur. J. Oral Sci. 2013, 121 Pt 2, 225-234. [CrossRef]

182. Facco, E.; Zanette, G.; Casiglia, E. The role of hypnotherapy in dentistry. SAAD Dig. 2014, 30, 3-6.

183. Roberts, K. Hypnosis in dentistry. Dent. Update 2006, 33, 312-314. [CrossRef]

184. Patel, B.; Potter, C.; Mellor, A.C. The use of hypnosis in dentistry: A review. Dent. Update 2000, 27, 198-202. [CrossRef]

185. Armfield, J.M.; Heaton, L.J. Management of fear and anxiety in the dental clinic: A review. Aust. Dent. J. 2013, 58, 390-531. [CrossRef]

186. Chebbi, Y. Cbd: A Natural Remedy for Dental Anxiety. 24 July 2020. Available online: https://www.myflossery.com/cbd-anatural-remedy-for-dental-anxiety/ (accessed on 1 April 2021).

187. Cohen, P. Treating Dental Anxiety with Natural Remedies Like CBD. 15 February 2019. Available online: https://www. healthworkscollective.com/treating-dental-anxiety-with-natural-remedies-like-cbd/ (accessed on 6 April 2021).

188. Özdemir, B.; Shi, B.; Bantleon, H.P.; Moritz, A.; Rausch-Fan, X.; Andrukhov, O. Endocannabinoids and inflammatory response in periodontal ligament cells. PLoS ONE 2014, 9, e107407. [CrossRef] [PubMed]

189. Jäger, A.; Setiawan, M.; Beins, E.; Schmidt-Wolf, I.; Konermann, A. Analogous modulation of inflammatory responses by the endocannabinoid system in periodontal ligament cells and microglia. Head Face Med 2020, 16, 26. [CrossRef] [PubMed] 
190. Kozono, S.; Matsuyama, T.; Biwasa, K.K.; Kawahara, K.-I.; Nakajima, Y.; Yoshimoto, T.; Yonamine, Y.; Kadomatsu, H.; Tancharoen, S.; Hashiguchi, T.; et al. Involvement of the endocannabinoid system in periodontal healing. Biochem. Biophys. Res. Commun. 2010, 394, 928-933. [CrossRef] [PubMed]

191. Van Klingeren, B.; Ten Ham, M. Antibacterial activity of delta9-tetrahydrocannabinol and cannabidiol. Antonie Van Leeuwenhoek 1976, 42, 9-12. [CrossRef]

192. Dariš, B.; Tancer Verboten, M.; Knez, Ž.; Ferk, P. Cannabinoids in cancer treatment: Therapeutic potential and legislation. Bosn. J. Basic Med. Sci. 2019, 19, 14-23. [CrossRef]

193. Hajishengallis, G.; Chavakis, T. Local and systemic mechanisms linking periodontal disease and inflammatory comorbidities. Nat. Rev. Immunol. 2021, 21, 426-440. [CrossRef]

194. Mammana, S.; Cavalli, E.; Gugliandolo, A.; Silvestro, S.; Pollastro, F.; Bramanti, P.; Mazzon, E. Could the Combination of Two Non-Psychotropic Cannabinoids Counteract Neuroinflammation? Effectiveness of Cannabidiol Associated with Cannabigerol. Medicina (Kaunas, Lithuania) 2019, 55, 747. [CrossRef]

195. Sukumar, K.; Tadepalli, A. Nexus between COVID-19 and periodontal disease. J. Int. Med. Res. 2021, 49. [CrossRef]

196. Marouf, N.; Cai, W.; Said, K.N.; Daas, H.; Diab, H.; Chinta, V.R.; Hssain, A.A.; Nicolau, B.; Sanz, M.; Tamimi, F. Association between periodontitis and severity of COVID-19 infection: A case-control study. J. Clin. Periodontol. 2021, 48, 483-491. [CrossRef]

197. Mucositis. Available online: https://oralcancerfoundation.org/complications/mucositis/ (accessed on 1 April 2021).

198. Cuba, L.F.; Salum, F.G.; Cherubini, K.; Figueiredo, M.A.Z. Cannabidiol: An alternative therapeutic agent for oral mucositis? J. Clin. Pharm. Ther. 2017, 42, 245-250. [CrossRef]

199. Pertwee, R.G. Emerging strategies for exploiting cannabinoid receptor agonists as medicines. Br. J. Pharmacol. 2009, 156, 397-411. [CrossRef]

200. Hanlon, K.E.; Lozano-Ondoua, A.N.; Umaretiya, P.J.; Symons-Liguori, A.M.; Chandramouli, A.; Moy, J.K.; Kwass, W.K.; Mantyh, P.W.; Nelson, M.A.; Vanderah, T.W. Modulation of breast cancer cell viability by a cannabinoid receptor 2 agonist, JWH-015, is calcium dependent. Breast Cancer 2016, 8, 59-71. [CrossRef]

201. Zhu, L.X.; Sharma, S.; Stolina, M.; Gardner, B.; Roth, M.D.; Tashkin, D.P.; Dubinett, S.M. Delta-9-tetrahydrocannabinol inhibits antitumor immunity by a CB2 receptor-mediated, cytokine-dependent pathway. J. Immunol. 2000, 165, 373-380. [CrossRef]

202. McKallip, R.J.; Nagarkatti, M.; Nagarkatti, P.S. Delta-9-tetrahydrocannabinol enhances breast cancer growth and metastasis by suppression of the antitumor immune response. J. Immunol. 2005, 174, 3281-3289. [CrossRef]

203. Marcu, J.P.; Christian, R.T.; Lau, D.; Zielinski, A.J.; Horowitz, M.P.; Lee, J.; Pakdel, A.; Allison, J.; Limbad, C.; Moore, D.H.; et al. Cannabidiol enhances the inhibitory effects of delta9-tetrahydrocannabinol on human glioblastoma cell proliferation and survival. Mol. Cancer Ther. 2010, 9, 180-189. [CrossRef]

204. Sharma, M.; Hudson, J.B.; Adomat, H.; Guns, E.; Cox, M.E. In Vitro Anticancer Activity of Plant-Derived Cannabidiol on Prostate Cancer Cell Lines. Pharmacol. Pharm. 2014, 05, 806-820. [CrossRef]

205. Solinas, M.; Massi, P.; Cinquina, V.; Valenti, M.; Bolognini, D.; Gariboldi, M.; Monti, E.; Rubino, T.; Parolaro, D. Cannabidiol, a non-psychoactive cannabinoid compound, inhibits proliferation and invasion in U87-MG and T98G glioma cells through a multitarget effect. PLoS ONE 2013, 8, e76918. [CrossRef]

206. Shrivastava, A.; Kuzontkoski, P.M.; Groopman, J.E.; Prasad, A. Cannabidiol induces programmed cell death in breast cancer cells by coordinating the cross-talk between apoptosis and autophagy. Mol. Cancer Ther. 2011, 10, 1161-1172. [CrossRef]

207. Cridge, B.J.; Rosengren, R.J. Critical appraisal of the potential use of cannabinoids in cancer management. Cancer Manag. Res. 2013, 5, 301-313. [CrossRef]

208. McAllister, S.D.; Soroceanu, L.; Desprez, P.Y. The Antitumor Activity of Plant-Derived Non-Psychoactive Cannabinoids. J. Neuroimmune Pharmacol. 2015, 10, 255-267. [CrossRef]

209. Gruetzmacher, K. The Pros and Cons of Using Medical Marijuana to Treat Oral Cancer. 13 September 2017. Available online: https://thefreshtoast.com/cannabis/the-pros-and-cons-of-medical-marijuana-and-oral-cancer/ (accessed on 6 April 2021).

210. CBD Oil for Oral Hygiene. 5 April 2018. Available online: https://cbdinstead.com/blogs/cbd-for-general-health/cbd-oil-fororal-hygiene (accessed on 6 April 2021).

211. CBD in Dentistry-Can Cannabis Cure Cavities? 13 October 2017. Available online: https://www.principesactifs.org/cbd-indentistry-can-cannabis-cure-cavities / (accessed on 6 April 2021).

212. Rettori, E.; De Laurentiis, A.; Zorrilla Zubilete, M.; Rettori, V.; Elverdin, J.C. Anti-inflammatory effect of the endocannabinoid anandamide in experimental periodontitis and stress in the rat. Neuroimmunomodulation 2012, 19, 293-303. [CrossRef]

213. Nakajima, Y.; Furuichi, Y.; Biswas, K.K.; Hashiguchi, T.; Kawahara, K.; Yamaji, K.; Uchimura, T.; Izumi, Y.; Maruyama, I. Endocannabinoid, anandamide in gingival tissue regulates the periodontal inflammation through NF-kappaB pathway inhibition. FEBS Lett. 2006, 580, 613-619. [CrossRef]

214. Arney, K. Cannabis, Cannabinoids and Cancer-The Evidence So Far. Cancer News, 25 July 2012. Available online: https: // news.cancerresearchuk.org/2012/07/25/cannabis-cannabinoids-and-cancer-the-evidence-so-far/ (accessed on 6 April 2021).

215. Vatican, J. Why Use CBD Oil Before Visiting the Dentist. Medical Daily, 22 May 2019. Available online: https://www.medicaldaily. com/why-use-cbd-oil-visiting-dentist-435364 (accessed on 6 April 2021).

216. Burhenne, M. CBD Oil Benefits for Better Dental \& Overall Health. 30 August 2019. Available online: https://askthedentist.com/ cbd-oil-facts/\#what-is-cbd-oil (accessed on 1 April 2021). 
217. Sybertz, A. CBD for Dental Pain, Anxiety, and Problems: Does It Work? The Healthy, 7 May 2021. Available online: https: //www.thehealthy.com/dental/cbd-for-dental-pain-and-anxiety/ (accessed on 6 April 2021).

218. What Are the Benefits of Hemp Seed Oil in Toothpaste? Humming Hemp, 3 March 2021. Available online: https: //thehumminggroup.com/benefits-hemp-oil-toothpaste/ (accessed on 6 April 2021).

219. Administrator. CBD and Bone Fracture Healing: The Best Data Published for Medical Marijuana in Fifty Years. BioTrack: The Leading Seed-to-Sale Cannabis Software. Available online: https:/ / www.biotrack.com/cbd-and-bone-fracture-healing-the-bestdata-published-for-medical-marijuana-in-fifty-years / (accessed on 6 April 2021).

220. McNamee, D. Marijuana 'Helps Bones to Heal'. 20 July 2015. Available online: https://www.medicalnewstoday.com/articles/29 7012.php\#4 (accessed on 6 April 2021).

221. Bab, I.; Zimmer, A.; Melamed, E. Cannabinoids and the skeleton: From marijuana to reversal of bone loss. Ann. Med. 2009, 41, 560-567. [CrossRef]

222. Stahl, V. Cannabis and Derivatives Thereof for the Treatment of Pain and Inflammation Related with Dental Pulp and Bone Regeneration Related to Dental Jaw Bone Defects. U.S. Patent No. WO2019030762A3, 19 March 2019.

223. Napimoga, M.H.; Benatti, B.B.; Lima, F.O.; Alves, P.M.; Campos, A.C.; Pena-Dos-Santos, D.R.; Severino, F.P.; Cunha, F.Q.; Guimarães, F.S. Cannabidiol decreases bone resorption by inhibiting RANK/RANKL expression and pro-inflammatory cytokines during experimental periodontitis in rats. Int. Immunopharmacol. 2009, 9, 216-222. [CrossRef]

224. Ways CBD Takes Care of Your Salivary Gland Infection. 31 August 2019. Available online: https://thecbdoil.online/cbd-forsalivary-gland-infection/ (accessed on 6 April 2021).

225. Benefits of CBG for Salivary Gland Infection: Salivary Gland Inflammation. 2019. Available online: https://thoughtcloud.net/ cbg-for-salivary-gland-infection/ (accessed on 12 May 2019).

226. CBD for Temporomandibular Joint Disorder (TMJ). 24 January 2020. Available online: https://hemppedia.org/cbd-for-tmj/ (accessed on 6 April 2021).

227. Qian, H.; Jin, Z.; Li, S.; Huo, N.; Han, C.; Sang, H. Activation of CB2 cannabinoid receptors: A novel therapeutic strategy to accelerate osseointegration of dental implants. Med. Hypotheses 2009, 72, 311-313. [CrossRef]

228. Werz, O.; Seegers, J.; Schaible, A.M.; Weinigel, C.; Barz, D.; Koeberle, A.; Allegrone, G.; Pollastro, F.; Zampieri, L.; Grassi, G.; et al. Cannflavins from hemp sprouts, a novel cannabinoid-free hemp food product, target microsomal prostaglandin E2 synthase-1 and 5-lipoxygenase. PharmaNutrition 2014, 2, 53-60. [CrossRef]

229. Richter, N. What Are Flavonoids? Comprehensive Guide. 10 March 2020. Available online: https:/ /wayofleaf.com/education/ what-are-flavonoids (accessed on 28 July 2020). 